\title{
Sediment characteristics and internal architecture of offshore sand ridges on a tideless continental shelf (western Mediterranean)
}

\begin{tabular}{|c|c|}
\hline Journal: & Earth Surface Processes and Landforms \\
\hline Manuscript ID & ESP-19-0458.R2 \\
\hline Wiley - Manuscript type: & Research Article \\
\hline $\begin{array}{r}\text { Date Submitted by the } \\
\text { Author: }\end{array}$ & $n / a$ \\
\hline Complete List of Authors: & $\begin{array}{l}\text { Durán, Ruth; Institute of Marine Sciences } \\
\text { Guillén, Jorge; Institute of Marine Sciences, Marine Geosciences } \\
\text { Ribó, Marta; The University of Auckland School of Environment } \\
\text { Simarro, Gonzalo; Institute of Marine Sciences, Marine geosciences } \\
\text { Muñoz, Araceli; Tragsa-SGP } \\
\text { Palanques, Albert; Institute of Marine Sciences } \\
\text { Puig, Pere; Institute of Marine Sciences }\end{array}$ \\
\hline Keywords: & $\begin{array}{l}\text { storm-dominated sand ridges, paleotopography, preservation, sand } \\
\text { resources, coastal protection, sustainability, bedforms, sedimentary } \\
\text { structures }\end{array}$ \\
\hline Abstract: & $\begin{array}{l}\text { An integrated approach, combining swath bathymetry, an extensive } \\
\text { dataset of vibrocores and high-resolution seismic reflection data was } \\
\text { used to assess the origin and evolution of offshore sand ridges in a } \\
\text { tideless continental shelf (Gulf of Valencia, western Mediterranean). The } \\
\text { sand ridges are located in the mid-outer shelf at } 55-85 \mathrm{~m} \text { water depth, } \\
\text { obliquely oriented to the shoreline. They are } 1.5 \text { to } 7 \text { m high, with a } \\
\text { wavelength between } 600 \text { and } 1,100 \mathrm{~m} \text {, and a mean height-wavelength } \\
\text { ratio of } 0.004 \text {. The sand ridges are composed of well-sorted medium } \\
\text { sand and are partially covered by a mud layer, evidencing a moribund } \\
\text { stage. They overlie an erosion surface that locally crops out at the } \\
\text { seafloor and is interpreted as the Holocene wave ravinement surface. In } \\
\text { the sediment cores, this surface corresponds to an erosional lag } \\
\text { composed of coarse sand and gravel with pebbles. Small topographic } \\
\text { irregularities on this surface are interpreted as shoreline-associated } \\
\text { features that may act as the precursor for ridge development. Their } \\
\text { preservation within the sand ridges could be related to the hardness of } \\
\text { these features. Internally, the sand ridges display high-angle dipping } \\
\text { reflections, indicating ridge migration towards the southeast in the } \\
\text { direction of the present-day sediment transport direction. The presence } \\
\text { of interbedded mud layers, associated with these reflections, indicates } \\
\text { intermittent episodes of mud deposition when active. The internal } \\
\text { architecture of some small ridges also provides new insights into their } \\
\text { transition from active to moribund state, as evidenced by a change in } \\
\text { the geometry of the internal units from progradational to aggradational } \\
\text { that are finally overlain by onlapping finer deposits over the flanks and in } \\
\text { the troughs. The Gulf of Valencia sand ridge field constitutes a valuable } \\
\text { potential sand resource of } 22 \cdot \text { million m3 of well-sorted medium and }\end{array}$ \\
\hline
\end{tabular}


coarse sand with limited mud content, that must be preserved as strategic sand reservoir.

\section{SCHOLARONE \\ Manuscripts}




\title{
Sediment characteristics and internal architecture of
} offshore sand ridges on a tideless continental shelf (western Mediterranean)

\author{
Ruth Durán ${ }^{1}$, Jorge Guillén ${ }^{1}$, Marta Ribó2 ${ }^{\text {, Gonzalo Simarro }}{ }^{1}$, Araceli Muñoz ${ }^{3}$, Albert \\ Palanques $^{1}$, Pere Puig ${ }^{1}$ \\ ${ }^{1}$ Institute of Marine Sciences, CSIC. Passeig Marítim de la Barceloneta 37-49, 08003 Barcelona, Spain. \\ rduran@icm.csic.es. ${ }^{2}$ School of Environment, University of Auckland, 23 Symonds Street, 1010, \\ Auckland, New Zealand. ${ }^{3}$ Tragsa-SGP, C/Julián Camarillo 6B, 28037 Madrid, Spain.
}

\section{ABSTRACT}

An integrated approach, combining swath bathymetry, an extensive dataset of vibrocores and high-resolution seismic reflection data was used to assess the origin and evolution of offshore sand ridges in a tideless continental shelf (Gulf of Valencia, western Mediterranean). The sand ridges are located in the mid-outer shelf at 55-85 m water depth, obliquely oriented to the shoreline. They are 1.5 to $7 \mathrm{~m}$ high, with a wavelength between 600 and 1,100 m, and a mean height-wavelength ratio of 0.004 . The sand ridges are composed of well-sorted medium sand and are partially covered by a mud layer, evidencing a moribund stage. They overlie an erosion surface that locally crops out at the seafloor and is interpreted as the Holocene wave ravinement surface. In the sediment cores, this surface corresponds to an erosional lag composed of coarse sand and gravel with pebbles. Small topographic irregularities on this surface are interpreted as shoreline-associated features that may act as the precursor for ridge development. Their preservation within the sand ridges could be related to the hardness of these features. Internally, 
the sand ridges display high-angle dipping reflections, indicating ridge migration towards the southeast in the direction of the present-day sediment transport direction. The presence of interbedded mud layers, associated with these reflections, indicates intermittent episodes of mud deposition when active. The internal architecture of some small ridges also provides new insights into their transition from active to moribund state, as evidenced by a change in the geometry of the internal units from progradational to aggradational that are finally overlain by onlapping finer deposits over the flanks and in the troughs. The Gulf of Valencia sand ridge field constitutes a valuable potential sand resource of $22 \cdot$ million $\mathrm{m}^{3}$ of well-sorted medium and coarse sand with limited mud content, that must be preserved as strategic sand reservoir.

Keywords: Bedforms, storm-dominated sand ridges, sedimentary structures, palaeotopography, preservation, sand sources, coastal protection, and sustainability.

\section{INTRODUCTION}

Offshore sand ridges, also named shoreface-detached ridges or drowned ridges, are large-scale bedforms observed on middle and outer continental shelves in both tidal-dominated (Berné et al., 2002; Liu et al., 2007) and storm-dominated environments (e.g. Swift et al., 1972; Bassetti et al., 2006; Simarro et al., 2015). In tidal-dominated settings, offshore sand ridges show elevations of 25 to $30 \mathrm{~m}$ with orientations that are $5^{\circ}-30^{\circ}$ rotated with respect to the peak tidal flow direction, generally in an anticlockwise sense in the northern hemisphere (Dyer and Huntley, 1999; Liu et al., 2007). Offshore sand ridges on storm-dominated continental shelves are smaller (up to $12 \mathrm{~m}$ high), and show an orientation oblique to the shoreline (e.g. Snedden et al., 2011; Simarro et al., 2015), caused by a steady alongshore current over a shelf with a transverse slope with respect to the coastline. They are mostly composed of fine to coarse sand (e.g. Swift and Field, 1981; Dalrymple and Hoogendoorn, 1997; Snedden and Dalrymple, 1999), and are characterised by a predominant asymmetric transverse profile with steeper downcurrent flanks (Bassetti et al., 2006; Li and King, 2007) and internal oblique reflections (Goff et al., 2005; Durán et al., 2018). 
The genesis of sand ridges can be explained by the stability model of Huthnance (1982), initially developed for linear sandbanks in tide-dominated settings and subsequently accepted for the formation of sand ridges on storm-dominated shelves (Dalrymple and Hoogendoorn, 1997; Snedden and Dalrymple, 1999). Based on this model, the requirements for sand ridge development include 1) availability of sufficient sand, 2) presence of currents capable of transporting sand-sized sediment; and 3) a pre-existing irregularity in the seafloor topography that initiates the flow-bed interaction. Sand source for ridge formation is commonly provided by marine reworking of ebb-tidal delta deposits (Swift et al., 1972; Figueiredo et al., 1982; McBride and Moslow, 1991), barrier-island and fluvial delta deposits (Swift et al., 1972; Bassetti et al., 2006), and periglacial deposits (Hoogendoorn and Dalrymple, 1986; Li and King, 2007), while sand transport is mainly attributed to near-bottom currents induced by storms, wind waves and/or tide-induced flows at the foot of the shoreface (Trowbridge, 1995; Goff et al., 1999; Snedden and Dalrymple, 1999). Regarding the initial topographic irregularity, the most common precursors for sand ridge formation are shoreline-associated features such as ebbtidal deltas (e.g. McBride and Moslow, 1991; Snedden et al., 1994; Snedden and Dalrymple, 1999; Robinson and McBride, 2006), nearshore bars, large dunes (Snedden and Dalrymple, 1999) or random topographic irregularities on the ravinement surface (Snedden and Dalrymple, 1999; Durán et al., 2018). It has been suggested that this precursor irregularity may later be removed or greatly reduced in size through subsequent erosion during sand ridge migration (McBride and Moslow, 1991; Snedden et al., 1999).

Following the work of Huthnance (1982), several studies were conducted on the physical mechanisms responsible for the generation of sand ridges on continental shelves. For tidal sand banks, such models have been developed and analysed by Hulscher et al. (1993) and de Swart and Hulscher (1995). The formation of sand banks appears to be due to the combined effect of residual circulations, which develop owing to tide-topography interactions (Zimmerman, 1981). For shoreface-connected ridges on storm-dominated shelves, several theories have been proposed for their formation and evolution. The first model was presented by Trowbridge 
(1995) who explained the formation of these ridges as morphodynamic self-organization related to frequent storm-driven currents. In this model, the physical mechanism for the development of the sand ridges is the offshore deflection of the storm-driven alongshore flow at the ridge crests and sediment convergence in the offshore direction due to the slope. Successive improvements of this model included bedload, suspended load sediment transport and a depth-dependent stirring of sediment by waves (Calvete et al., 2001). During sea level rise, the shorefaceconnected ridges became progressively detached from the shoreface, slowing their growth and decreasing their migration rate until they eventually drowned when the near-bed orbital velocity drops below the critical velocity for entrainment and transport of sediment (Nnafie et al., 2014), forming a field of isolated bedforms in deeper waters. At present, sand ridges on the middle and outer shelf are defined as active when they can develop or migrate, relict when there is no interaction with present-day processes, and moribund if sedimentary processes tend to degrade their morphology or modify their original characteristics (Yang, 1989; Dyer and Huntley, 1999). In a slightly different way, De Swart and Yuan (2018) suggest that moribund sand ridges occur when sand transport is absent in the entire ridge area (equivalent to relict sand ridges), whereas "quasi-active" sand ridges (Liu et al., 2007) are characterized by intermittent dynamics caused by the highest-energy events.

Offshore sand ridges have been widely described on modern continental shelves, and also have been identified in the sedimentary record. However, despite the abundance of evidence of modern sand ridges, unequivocal transgressive sandstone bodies as analogues of shelf ridges are scarce (Suter, 2006). The limited ocurrence of ancient sand ridges is mostly due to ambiguous interpretations of these sand bodies. Several marine sandstone bodies, initially interpreted as shelf sandstone deposits (Tillmand and Martinsen, 1984; Krause and Nelson, 1991), were subsequently reinterpreted as incised-valley deposits (Sullivan et al., 1997) or lowstand shoreline deposits (Walker and Bergman, 1993). Driven by the need to improve the interpretation of ancient sand ridges in the sedimentary record, new emphasis has been put on the definition of key criteria for the identification of ancient shelf-ridge deposits based on new 

data from both modern (Suter, 2006; Snedden et al., 2011) and ancient shelf ridges (Posamentier, 2002; Schwarz, 2012; Leva López et al., 2016). Therefore, further investigation is needed to fully understand how active sand ridges gradually become moribund and how these features are preserved in the geological record.

There is a high interest in understanding the formation and evolution of sand ridges on the midouter shelf because they may dissipate surface wave energy and thereby protect sedimentary coasts, and represent potential locations for offshore windfarm installations. Furthermore, offshore sand ridges constitute strategic resources and may be an important source of sediment to maintain beach stability (e.g. beach nourishments). During the last decade, the increasing shortage of sand around the world has forced governments to go farther offshore to obtain new sand supplies. Shoals, sand ridges and other sediment bodies developed on the mid and outer shelf (e.g. Schwab et al., 2013; Durán et al., 2015; Ribó et al., in press) are expected to serve as long-term sand resources for beach nourishment and coastal restoration projects.

In this work, we present a detailed analysis of the sediment characteristics and internal architecture of offshore sand ridges developed on a storm-dominated continental shelf, the Gulf of Valencia (GoV) continental shelf in the western Mediterranean (Fig. 1). Tidal action in the western Mediterranean Sea is very small, with tidal amplitudes of approximately $0.2 \mathrm{~m}$, so it is frequently considered as tideless (King and Williams, 1949). Tidal currents are very weak (few $\mathrm{cm} / \mathrm{s}$ ) and only detectable in absence of waves and winds (Guillén et al., 2002), with a negligible impact on morphodynamic processes. This hydrodynamic setting differs from other shoreface-connected sand ridges develop on storm-dominated continental shelves, such as the North Sea off Belgian and Dutch microtidal coasts, where tidal amplitude is higher than $1 \mathrm{~m}$, and tidal currents and storms are both important sediment stirring agents (Van de Meene, 1994).

The present study is based on an integrated approach combining swath bathymetry, an extensive dataset of vibrocores and high-resolution seismic reflection data. The cross-ridge seismic profile originally presented by Simarro et al. (2015) is herein re-examined by incorporating collocated 
129 (or nearly so) sediment cores in order to compare the fine-scale internal structure of the sand

130 ridges with the textural information provided by vibrocores. The aim of this work is to provide a 131 better understanding of: (1) the formation and long-term migration of offshore sand ridges on tideless continental shelves; (2) the transition from active to moribund sand ridges and their potential for preservation; and (3) the potential use of these bedforms as sand reservoirs for shoreline protection.

\section{STUDY AREA}

The continental shelf of the Gulf of Valencia (GoV) extends from the southern Ebro shelf (south of the Columbretes Island) to the promontory of Cap La Nao, in the western Mediterranean Sea (Fig. 1). It has a variable width with the shelf edge at $\sim 150 \mathrm{~m}$ water depth. The shelf is wider south of the Columbretes Islands (exceeding $47 \mathrm{~km}$ ), but it severely narrows towards the south ( $\sim 35 \mathrm{~km}$ wide) reaching its minimum width at the southern end off Cap La Nao, where it is only 15 km wide (Rey and Díaz del Río, 1983).

The GoV continental shelf is a storm-dominated environment with a source of sediment from riverine inputs and a marked seasonal wave climate (Maldonado et al., 1983; Young et al., 1983), with October-April being the most energetic period. The tidal amplitude in the study area is usually below $0.2 \mathrm{~m}$. The main river discharging in the area is the Turia River (Fig. 1), which shows a typical Mediterranean regime with most of the discharge concentrated in high magnitude and low frequency flood events (Martín-Vide, 1985; Martín-Vide et al., 2008). The mean discharge recorded by gauging stations in this river is around $14 \mathrm{~m}^{3} / \mathrm{s}$ with strong peaks higher than $400 \mathrm{~m}^{3} / \mathrm{s}$ (with extremes up to $3000 \mathrm{~m}^{3} / \mathrm{s}$ during the $1957 \mathrm{flood}$; Cánovas, 1958). In addition, short ephemeral streams flowing into the GoV. These streams carry very coarse material and experience very strong floods in Spring and Autumn when water discharge may be up to $590 \mathrm{~m}^{3} / \mathrm{s}$ (Sanjaume et al., 1996). Sediment inputs of the Turia River contribute towards the development of sand barrier beaches and those from the ephemeral streams develop pebble barrier beaches (Sanjaume et al., 1996). At present, the GoV continental shelf is characterised 
by relative sand starvation.

The water circulation in the GoV and over the Ebro continental shelf is strongly controlled by the wind pattern (Espino et al., 1998; Font, 1990), and local mesoscale events forced by wind bursts and by the Ebro River discharges (Salat, 1995; Salat et al., 2002). The along-shelf sediment flux towards SSW is dominant over the mean seaward cross-shelf flux, with maximum near-bottom sediment fluxes associated with storms (Young et al., 1983; Puig et al., 2001; Palanques et al., 2002). A hydrodynamic study focussing on the sand ridges area reveals that near-bottom shear stress, as generated during storm conditions, is able to resuspend and transport sandy and muddy sediments in the middle shelf (Simarro et al., 2015).

The stratigraphic record of the GoV continental shelf comprises a thick series of PlioQuaternary deposits composed of several barrier-lagoon systems, whose formation has been related to Late Quaternary stillstand periods (Rey and Diaz del Rio, 1983; Albarracín et al., 2013; Lobo et al., 2015), and their preservation is favoured by high subsidence rates (Albarracín et al., 2013). During the Holocene, rising sea levels resulted in the erosion of these deposits through wave ravinement, forming an erosive surface mantled by gravel and coarse sand that determines the baseline level of the present-day sedimentation on the GoV shelf (Rey et al., 1999). At present, sand and gravels, composed of mixed amounts of clastic and carbonate, cover the inner shelf (Fig. 1b), whereas a muddy blanket extends along the middle and outer shelf (Giró and Maldonado, 1983), with accumulation rates of about 1.3-1.9 mm/y (Maldonado et al., 1983; Young et al., 1983). Only in the central part of the continental shelf, an isolated area of sandy sediments occupies the middle shelf (Giró and Maldonado, 1983; Rey et al., 1999).

The present-day morphology of the continental shelf displays a complicated topography determined by the presence of modern and relict features, which are the result of the glacioeustatic oscillations from the Upper Pleistocene to the Holocene. Modern prodeltas and infralittoral prograding wedges, and carbonate-cemented relict coastal barrier islands (i.e., beachrocks) dominate the inner shelf (Giró and Maldonado, 1983; Rey and Díaz del Río, 1983; 
Alcántara-Carrió et al., 2013), whereas large sediment bodies, interpreted as sand ridges, are found on the middle shelf (Maldonado et al., 1983; Albarracín et al., 2014; Simarro et al., 2015). The sand ridges occur between 55 and $85 \mathrm{~m}$ water depth showing a predominant NE-SW orientation, oblique $\left(\sim 50^{\circ}\right)$ to the isobaths (Maldonado et al., 1983; Rey and Díaz del Río, 1983; Albarracín et al., 2014) (Fig. 2a). The ridge heights (H) range from 1.5 to $7 \mathrm{~m}$, the wavelength (L) from 600 to 1,100 m, the crestline length from 1,100 to 3,100 m (Simarro et al., 2015), with a mean relation $\mathrm{H} / \mathrm{L}$ of 0.004 . These ridges are asymmetric with the steeper lee face on the southeast side of the crest, consistent with the present-day net sediment transport direction.

\section{DATA AND METHODS}

The analysis of the GoV sand ridges is based on the interpretation of swath bathymetry, very high-resolution seismic reflection data and sediment cores (Fig. 2). Swath-bathymetry was acquired in 2010 using the Elac Seabeam 1050D $180 \mathrm{kHz}$ multibeam echosounder mounted on the R/V García del Cid. Sound velocity data were obtained from multiple conductivity, temperature and depth (CTD) casts collected during the cruise. Post-processing of multibeam data (including correction for heading, depth, pitch, heave and roll) was conducted using the CARIS HIPS and SIPS Hydrographic Data Processing System. Tidal and sound velocity corrections were applied and the sounding data were cleaned to remove erroneous soundings. Filtered soundings were gridded into $4 \mathrm{~m}$ resolution bathymetric surface with $100 \%$ coverage. The gridded multibeam data sets were projected to Universal Transverse Mercator (UTM) $30 \mathrm{~N}$ zone projection in the World Geodesic System (WGS) 1984 geographic coordinated system. Crests and troughs of the sand ridges were defined using the bathymetric position index (BPI), as modified from the topographic position index as defined by Weiss (2001).

Information from a total of 279 vibrocores was provided by the Spanish Ministry of Agriculture, Food and Environment (Sub-Directorate General for Coastal Protection) (Fig. 2b). Vibrocores were collected in 2007 onboard the R/V Investigador. Positioning was determined with a differential GPS. Vibrocores were 4-5.5 m long with a diameter of $90 \mathrm{~mm}$. Each sediment core 

was sub-sampled every $0.5 \mathrm{~m}$ for grain size analysis, resulting in 2754 samples. Grain-size distributions were computed via sieving with the following diameters: $4.5,2,1,0.71,0.5,0.42$, $0.25,0.16,0.125,0.074$ and $0.063 \mathrm{~mm}$. Mean values and sorting were calculated geometrically (in metric units) using the graphical method of Folk and Ward (1957), included in the GRADISTAT software (Blott and Pye, 2001). The following classes were used to describe the sediment samples: gravel (sediment size fractions $>2 \mathrm{~mm}$ ), coarse sand $(2-0.5 \mathrm{~mm})$, medium sand $(0.5-0.25 \mathrm{~mm})$, fine sand $(0.25-0.063 \mathrm{~mm})$ and mud $(<0.063 \mathrm{~mm})$. The analysis of sand grain composition was based on binocular microscope examination of grains. No direct access to the vibrocore samples was possible, preventing further detailed analyses. Bathymetric and sediment data were integrated using Esri's ArcGIS 10.5 software. A surficial sediment texture distribution map was based on the Folk classification (1954).

A high-resolution seismic reflection profile across the sand ridges was obtained in 2011, using a Kongsberg TOPAS PS 018 Parametric sub-bottom profiler installed onboard the R/V Vizconde de Eza by the Spanish Secretariat for the Sea and the Spanish Oceanography Institute. The TOPAS transmitted each $1-2 \mathrm{~s}$, with a beam angle of approximately $5^{\circ}$, and a modulated frequency sweep ranging between 16 and $20 \mathrm{kHz}$, resulting in a vertical resolution of about 15 $\mathrm{cm}$. Standard processing was applied to the seismic data, including time variable gain (TVG) amplifying during acquisition and band-pass filtering. High-resolution seismic reflection data were imported as SEG-Y files into the KINGDOM SUITE ${ }^{\mathrm{TM}}$ software for interpretation. Seismic reflection data were complemented with a previous dataset collected in 1983, using a $3.5 \mathrm{kHz}$ sub-bottom profiler installed onboard the R/V García del Cid, available from the database of the Marine Science Institute, CSIC (Figs. 1 and 2b). Sound velocities used for timeto-depth conversion were $1550 \mathrm{~m} \mathrm{~s}^{-1}$ in water and $1650 \mathrm{~m} \mathrm{~s}^{-1}$ in sediment. Seismic reflection lines are represented in two-way travel time (milliseconds TWTT), and gradient values are given in degrees. Individual sand ridges located along the seismic profile acquired in 2011 are named as ridges I to XI to assist in identification in the following discussion (Fig. 2). 


\section{RESULTS}

\subsection{The basal surface of the sand ridges}

The high-resolution seismic reflection profile displays a strong reflector at the base of the sand ridges, named hereafter as basal reflector, which corresponds to a major erosion surface that can be traced along the whole continental shelf (Fig. 3). This surface exhibits a rough topography with high-reflectivity mounded morphologies and high-relief areas from beachrocks that locally crop out at the seafloor (Fig. 3). The gradient of this surface is $0.2^{\circ}$ in the middle shelf and increases to $0.5^{\circ}$ in the outer shelf. In the area of the sand ridges, the basal reflector underlies the sand ridges and intersects, or comes very close to, the seafloor in the deeper parts of the troughs, as observed from the sand ridges VI to IX (Fig. 4). Across the sand ridge field (Fig. 4), the basal surface dips gently $\left(0.04^{\circ}\right)$ towards the southeast from $\sim 92 \mathrm{~ms}(\sim 72 \mathrm{~m})$ in the northern sector to $\sim 104 \mathrm{~ms}(\sim 81 \mathrm{~m})$ in the southern one, and shows an irregular topography.

Sediment cores penetrating the basal reflector evidence a layer of gravel with pebbles at depths between 1.5 and $5.5 \mathrm{~m}$ below the seafloor (mbsf) in the sand ridges (e.g. cores 107, 113, 114, 116 and 190; Figs. 4 and 5) and at 0.5-2.5 mbsf (e.g. cores 100 and 108; Fig. 4) or locally exhumed at the seafloor (e.g. core 193; Fig. 4) in the troughs between ridges. An example of this coarse lag at the base of the sand ridges can be observed in sand ridge IX, where the sediment cores penetrate almost $3 \mathrm{~m}$ into the seafloor through the basal reflector (Fig. 5). At the core location, this reflector lies $\sim 2 \mathrm{~ms}(\sim 1.6 \mathrm{~m})$ below the seafloor. The grain size analysis reveals a surficial layer of mud and sand (fining upwards) over a layer of gravel that extends from 1.7 to 2.7 mbsf. Sediment samples from the coarse lag are composed of gravel $(60 \%$ on average, up to $98 \%)$ and coarse sand $(21 \%$ on average, up to $68 \%)$ with a low mud content $(<$ 4\%) and median grain sizes up to $4.75 \mathrm{~mm}$ (Fig. 6g). Core photographs show abundant mixtures of cobbles $(64-256 \mathrm{~mm})$ and boulders $(>256 \mathrm{~mm})$ (Fig. 7). This coarse sediment layer provides the only likely candidate for generating the impedance contrast necessary to produce this strong reflector. A similar correlation was observed in most vibrocores collected along the seismic line 
(e.g. cores 27, 30 and 116; Fig. 4) with the exception of some sediment cores where the basal

260 reflector is associated with a change from fine sediment above to poorly sorted sand below (e.g.

261 cores 62 and 108; Fig. 4). The lack of evidence of the coarse lag in these cores could be due to

262 the reduced thickness of this deposit and the sampling method. The coarse lag is commonly

263 thicker than $0.5 \mathrm{~m}$, which corresponds to the sampling frequency.

264 This coarse deposit marks a sharp lithological passage with the underlying deposits, which

265 display significant lateral variability (Fig. 4). In the northern sector of the sand ridge field,

266 underlying sediments are composed of moderately to well-sorted fine sands $(67 \%$ on average,

267 up to $95 \%)$ with a variable content of medium (1-51\%) and coarse (0-23\%) sand (Figs. 4 and

268 6b). Conversely, in the southern sector of the sand ridge field, sediments beneath the coarse lag

269 are mostly composed of coarse sand (23\% on average, up to $58 \%)$ and gravel (36\% on average,

270 up to 66\%) (Figs. 4 and 6c). The change in the sediment characteristics of the lag deposit and

271 the underlying sediments, coarsening towards the south, is also evidenced by the seismic

272 attributes of the basal surface that becomes more irregular and reflective with poor seismic

273 penetration, particularly under the sand ridges (Fig. 4).

\subsection{Sediment characteristics of the sand ridges}

The seismic unit overlying the basal erosion surface corresponds to the sand ridges unit. The thickness of this unit varies between 0 and $2.4 \mathrm{~m}$ in the troughs, but it can be up to $8.2 \mathrm{~m}$ in sand ridge crests (Fig. 4). The sand ridges are commonly asymmetric with the steepest slope facing the SE, with the exception of some smaller ridges that show a nearly symmetric profile (e.g. ridges I, III and VII). The dip angle of the steeper slope is $0.7^{\circ}-3.5^{\circ}\left(1.9^{\circ}\right.$ on average), whereas the angle of the gentle slope is $0.5^{\circ}-1.6^{\circ}\left(1.0^{\circ}\right.$ on average), with a slope ratio of $\sim 1: 2$. This slope ratio indicates that sand ridges are commonly asymmetric.

The surficial sediment distribution on the sand ridge field reveals the presence of a discontinuous mud domain that is mostly composed of mud ( $75 \%$ on average) and medium sand ( $15 \%$ on average) with a low fine ( $6 \%$ on average) and coarse ( $4 \%$ on average) sand content. 
285 The mud content within this domain increases towards the north up to $98 \%$ in the northernmost 286 sector (Fig. 8b). This mud domain preferentially occupies the troughs between ridges, with the 287 exception of the northernmost sand ridges where it extends over the ridges crest (e.g. ridge I and part of ridge IV; Fig. 8a). Surficial sediment on the crests of sand ridges are mostly composed of medium $(40 \%$ on average) and coarse $(8 \%$ on average) sand with low gravel content $(<8 \%)$.

The thickness of the mud layer varies between 0.5 and $1.5 \mathrm{~m}$ (up to $3 \mathrm{~m}$ ) increasing towards the north (Figs. 4 and 8c). The minimum thickness of this layer occurs on the crest of the sand ridges, as well as in the troughs between ridges VI to IX, where a coarse-grained deposit (up to $40 \%$ of gravel) is emergent at the seafloor (Fig. 4). In addition to this north-south textural pattern, important crest/trough surficial textural variations were also observed. Mud content is high in the troughs between ridges (mud content of 60-90\%) decreasing towards the crests, which are characterised by sandy sediments with a mud content of 10-30\%. Along the crest of

297 individual ridges, the mud content also increases from the centre to the outside edges (Figs. $2988 b, c)$.

Four types of sediment cores have been distinguished based on their main sedimentological characteristics, showing a gradual transition among the different categories. Types 1 and 2 are dominated by coarse-grained sediment and are preferentially located on the crest and flanks of the sand ridges, whereas types 3 and 4 are dominated by fine-grained sediments and are located in the troughs.

Type 1 cores, located on the crest of the sand ridges (Fig. 9a), are characterised by a sand layer with a low mud content $(<20 \%)$ that extends along the entire length of the core (e.g. VC10 and VC28; Fig. 9b) and hits the coarse lag when the sediment core penetrates the base of the sand ridges (e.g. VC114 and VC121; Fig. 9b). The sand layer consists of well-sorted medium (56\% on average, up to $83 \%)$ and coarse (29\% on average, up to $87 \%$ ) sands with up to $20 \%$ of mud and $10 \%$ of gravel (Fig. 6d). Binocular microscope observations indicated that these sediments are composed of subangular and subrounded quartz grains (>94\%) with a low content of 
311 bioclasts $(2-5 \%)$ and rock fragments (1-2\%). The biogenic fraction is composed of fragmented

312 gastropods, foraminifera, bivalves and echinoderm spicules.

313 Type 2 cores are located on the crest and flanks of the sand ridges (Fig. 9c). In these sediment cores, the layer of well-sorted medium and coarse sand appears covered by a surficial layer of mixed sediment, consisting of sand (33\% on average, up to $68 \%)$ and mud $(69 \%$ on average, up to $98 \%$ in the northernmost sand ridges) (Figs. 9d and 6c). The thickness of this surficial layer

317 of mud and sand is commonly $0.3-1 \mathrm{~m}$ thick, but it can be up to $2.5 \mathrm{~m}$ at the edge of some ridges

318 (e.g. sediment core 275; Fig. 9d).

Locally, the sandy facies of Types 1 and 2 cores display interbedded mud layers at different depths (e.g. cores 10 and 105 in Fig. 9). The interbedded mud layers exhibit similar textural characteristics of the surficial mud layer; they are mostly composed of mud with a variable content of fine and medium sand (Fig. 6b).

Type 3 cores appear preferentially in the troughs between the sand ridges (Fig. 10a). They are characterised by the presence of a surficial mud layer (0.5-1 m thick) with $55-85 \%$ of mud (Figs. 6a and 10b). Mud content within this layer decreases from the troughs towards the flanks of the sand ridges. As noted above, considerable lateral variability exists among these cores. In the northern sector of the sand ridge field, Type 3 sediment cores are characterised by a surficial mud layer overlying the coarse lag. A thick (up to $4 \mathrm{~m}$ ) layer of moderately to well-sorted fine sand dominates the sediment cores below the coarse lag (e.g. cores 25 and 264; Figs. 4, $6 \mathrm{f}$ and 10b). A similar pattern can be also found in some Type 2 sediment cores, such as VC 275 (Fig. 9), where they are located on the lower region of the sand ridge flank, near the trough, evidencing the gradual change in the grain-size trends between the sand ridges and the troughs between ridges. Conversely, Type 3 sediment cores in the southern sector are more

334 heterogeneous in grain size with a higher content of coarse sand and gravel (e.g. cores 193 and 211; Figs. 4, 6e and 10b). Locally, the coarse lag is located at less than $1 \mathrm{~m}$ below the seafloor with absence of an overlying layer (e.g. cores 100, 193; Figs. 4 and 9b). 
337 Lastly, Type 4 cores are located in the troughs between ridges in the northernmost sector of the 338 sand ridge field (Fig. 10c). They are characterised by a thick (1-3.5 m) surficial mud layer with 339 a mud content between $85 \%$ and $98 \%$ (Fig. 10d). Similar to Type 3 cores, thin, intercalated 340 coarse beds are also observed at different depths in Type 4 cores.

\subsection{Internal structure of the sand ridges}

The internal architecture of the sand ridges is well established in the smaller sand ridges, such as the sand ridges IV, IX and XI (Figs. 5 and 11). In the largest ridges, the seismic profile displays a thick pattern of parallel reflections that mimic the seafloor, corresponding to an artefact of the acoustic signal that masks the internal structure of the sand ridges (Fig. 4). Small sand ridges, like sand ridge IV, are characterised by steep clinoforms and a convex, upper boundary surface (Fig. 11). The clinoforms have a thickness up to $10 \mathrm{~ms}(\sim 8.25 \mathrm{~m})$ and dip toward the SE. Locally, small mound-like features with low relief (up to $1 \mathrm{~m}$ high) and limited extend (less than $350 \mathrm{~m}$ wide) are identified within the sand ridges (Figs. 4 and 11). In some small ridges, such as ridge IV, different internal subunits can be identified (Fig. 11): an aggradational lower unit, named Unit 1, that comprises internal convex reflectors; a progradational seismic unit (Unit 2), characterised by relatively high-angle clinoforms with $1-1.5^{\circ}$ dipping foresets; a thin $(\sim 0.3 \mathrm{~m}$ thick) ridge-conform unit (Unit 3) characterised by slightly divergent internal reflections with gentle dipping angle (around $0.7^{\circ}$ ) that onlap onto high-angle clinoforms, and an upper unit (Unit 4). These units, identified in the seismic profiles, are consistent with the textural variation observed in the sediment cores across the sand ridges (Fig. 11). The high-angle clinoforms (Unit 2) consist of medium and coarse sand with a low content of mud, corresponding to the lower unit identified in the Type 2 cores (VC 116), located on the flanks of the sand ridges. The upper aggradational unit (Unit 3) and the low-angle divergent seismic facies (Unit 4) can be correlated to the surficial unit of mixed sediment (mud and sand) observed in the Type 2 cores. This surficial layer becomes thicker with increasing distance from the crest ridges, with maximum 
values in the trough, corresponding to the surficial layer described in the Type 3 cores (e.g. VC 113). A coarse lag deposit corresponding to the basal reflector of the sand ridges is observed in both sediment cores.

Seismic facies between the sand ridges are characterised by subparallel, aggradational reflections with a very low dipping angle towards the south corresponding to fine-grained sediment in the sediment cores (Figs. 4 and 11), indicative of low-energy sediment fill. Below the basal reflector, the seismic facies exhibit a semi-transparent pattern due to the thickness of the sand ridges. Laterally continuous low-angle to flat seismic reflections can be identified below the basal reflector only under the northern sand ridges (e.g. sand ridges IV and IX; Fig. 4). Locally, buried mound-liked features can be identified in these strong reflectors. These facies evolve southwards to opaque facies due to the poor penetration of the seismic waves below the coarse sediments of the erosional surface (Fig. 4). Detailed seismic analysis of small sand ridges also revealed the presence of high-angle clinoforms under the sand ridges (Fig. 11).

\section{DISCUSSION}

\subsection{Interplay between the palaeo-topography and sand ridge formation and migration}

The analysis of high-resolution seismic reflection data document a basal reflector beneath the sand ridges that corresponds to a regionally recognized erosion surface, previously interpreted as the Holocene ravinement surface (Albarracín et al., 2014; Simarro et al., 2015). Sediment cores penetrating this surface intersect a thin (commonly less than $0.5 \mathrm{~m}$ thick, Fig. 4), coarsegrained deposit composed of siliciclastic coarse sand and gravel with pebbles and cobbles associated to this surface, which supports this interpretation. This coarse-grained deposit corresponds to a transgressive lag formed by shoreface erosion of the underlying strata during transgression. In the southern sector of the sand ridge field, this lag marks a sharp lithological change from poorly-sorted coarse sand and gravels in the underlying deposits to well-sorted medium sand reworked in the sand ridges, suggesting a transition from coastal plain to marine conditions (drowning phase). The underlying sediments are found to be coarser towards the 
southeast and these coarse-grained deposits also thicken towards the southeast (Fig. 4), most likely due to the proximity of coastal streams supplying coarser material. The ravinement surface locally crops out at the seafloor in some troughs between the ridges, evidencing relative sand starvation. At present, the source of the sandy sediment should be limited to the winnowing of coarse deposits associated with the erosion of this surface. The highly reflective mounded morphologies, as identified in the ravinement surface, are similar to those described on other continental shelves, such as US Atlantic shelf (Goff et al., 2005; McHugh et al., 2010), in the English Channel (Mellet et al., 2012; Mellet and Plater, 2018), on the South African shelf (Petrorius et al., 2016), in the Gulf of Cádiz (Lobo et al., 2018) and in the North Sea (Emery et al., 2019). On the US Atlantic shelf, irregular highs with chaotic reflections have been related to coarse-grained, armoured shallow-water deposits (Goff et al., 2005) or coastal headlands (Schwab et al. 2014). On the South African shelf, offshore Durban, acoustically opaque and isolated ridges with local high-relief pinnacles were interpreted as cemented coastal deposits such as beachrocks and/or aeolianites within palaeo-barrier complexes (Green et al. 2013; Salzmann et al. 2013; Pretorius et al. 2016). On the Dogger Bank (North Sea), elongated, mounded morphologies bounded by a continuous high-amplitude top reflector were also interpreted as remnants of early phases of barrier building (Emery et al., 2019). Very similar facies and morphologies have been reported on the Mediterranean continental shelves of western Sardinia (De Falco et al., 2015), Gulf of Lion (Tesson et al., 2015) and Murcia (Durán et al., 2018), also interpreted as preserved coarse-grained, commonly lithified coastal deposits. A similar interpretation can be inferred for the irregular mounds in the GoV based on their seismic characteristics. The high degree of acoustic impedance suggests their development in a

411 nearshore environment as cemented beach deposits or armoured shallow-water deposits associated to palaeo-barrier complexes. The presence of buried mound-like features, and high-

413 angle clinoforms below the ravinement, are also evidence of drowned barriers within the 414 stratigraphic record. This agrees with the identification of carbonate-cemented relict coastal 415 barrier islands and associated coastal lagoons of the inner shelf (Rey and Diaz del Rio, 1983; 416 Alcántara-Carrió et al., 2013; Albarracín et al., 2013). 
417 These shoreline-associated features, preserved over the ravinement surface, may act as the

418 precursor for sand ridge development, producing an initial bathymetric irregularity large enough

419 to disturb linear water flows under suitable conditions of available sand and active storm-

420 induced bottom-currents at the foot of the shoreface. Morphodynamic models demonstrated that

421 sand ridges may develop spontaneously as free instabilities of the coupled water-bottom system

422 (e.g. morphodynamic self-organization) (Huthnance, 1982; Trowbridge, 1995; Calvete et al.,

423 2001). However, their evolution is much faster when they develop from a suitable previous

424 topography (Nnafie et al., 2014).

425 As ridges migrate, sediment is eroded from the up-current (stoss) flank relative to the net transport direction and deposited on the down-current (lee) side. The analysis of high-resolution seismic reflection data has revealed the presence of internal oblique reflections dipping towards the southeast in the GoV sand ridges, providing insights into their migration (Figs. 5 and 11). As ridges migrate, sediment is eroded from the up-current (stoss) flank relative to the net transport direction and deposited on the down-current (lee) side, forming high-angle foresets. The presence of dipping reflections within ridges has been described also in other storm-dominated ridges in the Mediterranean (Bassetti et al., 2006; Lo Iacono et al., 2010; Durán et al., 2018) and on North American Atlantic continental shelves (Goff et al., 1999; Li and King, 2007, Snedden et al., 2011; Goff and Duncan, 2012). In the New Jersey sand ridges, burrowed, low-density mud beds within the high-energy upper ridge unit were interpreted as accretionary surfaces associated with cessation of migration followed by reactivation of ridge movement (Snedden et al., 2011). In the GoV sand ridges, the presence of thin mud beds interbedded in Type 1 and 2 cores (on crests and flanks) suggests intermittent episodes of mud deposition, in an otherwise sandy storm-dominated setting, during the active phase of the sand ridges. Mud drapes would be associated with high riverine fine sediment discharges directly deposited on the shelf or 441 transported offshore during storms and settled from suspension in the waning stage of storms.

442 Subsequent increased wind-driven currents during storms would most likely increase the migration rate. The alternative explanation of intercalated mud drapes on lee slopes of sand 
ridges by migration of small superimposed bedforms (Reesink and Bridge, 2007) is unlikely here, since no superimposed bedforms were observed.

Observations on the Atlantic Margin off New Jersey and Sable Island revealed that in the absence of mud-burying morphologies, sand ridges at water depths shallower than $50 \mathrm{~m}$ display active sand dunes on their flanks, which are responsible for sand ridge migration (Goff et al., 1999). In deeper waters ( $>50 \mathrm{~m})$, however, sand ridges appear to cease evolving via dune dynamics (Goff et al., 2005), although continued modification is accomplished through winnowing and erosive sculpting (Goff et al., 1999; Goff and Duncan, 2012). At present, sand ridges in the GoV show no evidence of migration, as indicated by the presence of a continuous mud blanket, associated to riverine fine sediment discharges, that covers part of the sand ridge field, particularly in the northern sector (Fig. 8).

The degree to which a ridge has migrated has important stratigraphic implications for the internal structure of the ridge. Bedform migration and growth (passing and deepening of the troughs) can excavate deeply into the substrate below the sand ridges, progressively destroying evidence of its precursor irregularity (Snedden and Dalrymple, 1999) and providing an addition to wave erosion in the formation of the ravinement surface (Goff, 2014). The nature of the initial irregularity and the degree of subsequent migration can explain the diversity of sand ridge characteristics. Based on the extent to which a ridge retains evidence of its precursor irregularity, MacBride and Moslow (1991) and Snedden and Dalrymple (1999) differentiate between partially evolved ridges close to, or attached to, the shoreline (Snedden et al., 1994; Robinson and McBride, 2006) and fully evolved ridges in the middle shelf (Snedden et al., 1994; Dalrymple and Hoogendoorn, 1997; Bassetti et al., 2006). The internal architecture of the GoV sand ridges reveals recognizable evidence of their precursor irregularity. The preservation of the initial irregularity within these sand ridges could be related to the apparent hardness of these basal features. Common precursors for sand ridge development described in other continental shelves include ebb-tidal deltas and sand bars (e.g. McBride and Moslow, 1991; 
more easily eroded. However, the coarse nature of the precursor for the GoV ridges (coarsegrained or cemented) makes them highly resistant to erosion, thus favouring their preservation. Limited migration of the sand ridges, as evidenced by the predominance of aggradational over progradational facies in seismic data, may also has contributed to reduce erosion of underlying sediments and to maintain the characteristics of the initial paleotopography.

\subsection{Evolution from active to moribund sand ridges: potential of preservation}

The current morphology, sediment characteristics and internal structures of the GoV sand ridges indicate that they can be found at two different stages of evolution. The northern sand ridges (sand ridges I to IV) show gentle morphology and are buried by a thick mud layer, suggesting that these bedforms would be at the last stage of their geological evolution. This is supported by the internal architecture of these ridges that changes from progradational to aggradational and, ultimately, onlapping finer deposits over flanks and in troughs, providing evidence of the transition from active to moribund state (Fig. 11). The mud layer that covers the sand ridges is part of a large mud belt that extends along the middle shelf, with the exception of a small area within the sand ridge field, dominated by sandy sediments (Giró and Maldonado, 1983; Rey et al., 1999; Fig. 1). The burial of these sand ridges by the mud blanket should favour the preservation of these ridges on the middle shelf.

The internal architecture of these ridges also provides useful information for the identification of analogous ancient isolated marine sand bodies in outcrop and the subsurface. The GoV sand ridges have some common key characteristics that are used as diagnostic criteria for shelf ridges (Snedden et al., 2011; Schwarz, 2012; Leva Lopez et al., 2016). These diagnostic criteria include: sand ridge detachment from coeval shoreline deposits; an orientation oblique to the shoreline; a sharp basal unconformity with low topographic relief; presence of dipping, muddraped internal surfaces; uniform grain-size with no significant grain gradation within the sand ridge unit; and a non-erosional upper-boundary surface with a convex up geometry and transitions into marine muds. In addition, new recognition characteristics can be derived from 
497 the analysis of the GoV sand ridges. The different changes in geometry of the internal units 498 (aggradation, migration, ridge-conform aggradation (no migration) and onlapping of finer 499 deposits over flanks and in troughs) provide evidence of the growth and final stage of evolution 500 of sand ridges that gradually become moribund until being covered by mud.

501 Whereas the internal structures of the northern sand ridges provide evidence of their 502 degradation, the morphology and sediment characteristics of the sand ridges in the southern 503 sector of the sand ridge area (ridges V to XI) differs from moribund ridges. Sand ridges V to XI 504 are mainly composed of medium sand with a thin mud layer that pinches out towards the crest 505 of the sand ridge and increases their thickness towards the troughs (Figs. 4 and 8), evidencing 506 preferential accumulation of fine sediment between ridge crests. Resuspension processes observed on the ridges suggest that sediment dynamics (preferentially at the crest) still occur at present (Simarro et al, 2015). The mud drape may therefore be removed from the ridge crest, but it is preserved in the troughs due to a slight reduction in current velocity.

Active sand ridges are commonly characterised by an asymmetrical cross-section with maximum slope of the lee-side up to $7^{\circ}$ and stoss-side slopes of $\sim 1^{\circ}$ (Stride, 1982). The higher slope gradients $\left(\sim 1.5^{\circ}\right.$ on average $)$ are found in active shoreface-connected sand ridges, whereas active offshore sand ridges are gentler (Swift and Field, 1981) (Fig. 12). Conversely, the transverse profile of moribund ridges is gentler, with a mean steep slope of $1^{\circ}$ (up to $2.3^{\circ}$ ) and a mean gentle slope of $0.5^{\circ}$ (Stride, 1982; Durán et al., 2018). The sand ridges in the GoV sand ridges field show gentle flanks ranging from $0.5^{\circ}$ to $1.6^{\circ}$ ( $1^{\circ}$ on average), and steep flanks between $0.7^{\circ}$ and $3.5^{\circ}\left(1.9^{\circ}\right.$ on average) (Fig. 12), being the southern ones the steepest (mean gentle flanks of $1.13^{\circ}$ and mean steepest flank of $2.21^{\circ}$ ). These values are higher than those reported for other moribund sand ridges (Stride, 1982; Swift and Field, 1981; Durán et al., 2018). Indeed, the GoV sand ridges are steeper than other active offshore sand ridges described on the Atlantic continental shelf ( $\mathrm{Li}$ and King, 2007; Snedden et al., 2011). For instance, active offshore sand ridges near Sable Island show gentle slopes of $0.49^{\circ}$ and steep slopes of $0.58^{\circ}$ on average (Li and King, 2007). On the New Jersey middle shelf, active sand ridges show average 
gradients between $0.4^{\circ}$ and $1.0^{\circ}$ (Snedden et al., 2011).

525

At a regional scale, it could be predicted that the steepness and asymmetry of the sand ridges would change with increasing water depth. Observations in Sable Island and the New Jersey continental shelves revealed that sand ridges become gentler and more asymmetrical with depth (Swift and Field, 1981; Goff et al., 1999; Li and King, 2007) (Fig. 12). In the Western Mediterranean, sand ridge asymmetry increases from $\sim 2: 3$ in the Ebro Delta shoreface ridges (Guerrero et al., 2018) to 1:2 in the Murcia and GoV offshore ridges (Durán et al., 2018; this work), showing a similar pattern to the NW Atlantic sand ridges. Moribund offshore sand ridges on the Murcia middle shelf are also gentler than active sand ridges on the Ebro Delta, in agreement with the transition from active nearshore to moribund offshore ridges. However, this tendency is not observed in the GoV southern sand ridges, which are even steeper than the Ebro Delta ridges (Fig. 12), suggesting that these ridges are not completely inactive and could be considered as "quasi-active" sand ridges as defined in other areas (Liu et al., 2007).

The maintenance of the ridge morphology in this area of the sand ridge field would be explained by the local hydrodynamics. Boundary-layer hydrodynamic measurements conducted on the sand ridge field showed evidence of active wave and current sediment resuspension and transport episodes during a major storm (Simarro et al., 2015). The influence of the wave field on the resuspension process was established in the initial part of the storm, whereas wavecurrent shear stress and advective processes dominated in the second half of the storm. The wave-current near-bottom shear stresses generated during storm conditions were able to mobilize the first centimeters of the surface sediment (mud and sand) in this area, producing a net transport towards the SE, oblique (around $20^{\circ}$ ) to the sand ridge field. Therefore, although the large sand ridges in the GoV do no migrate, sediment dynamics affecting sand ridges during storms likely contribute to the maintenance of their morphology, preventing their burial by fine sediment.

\subsection{Sand ridges as potential borrow areas}


550 About 25 billion $\mathrm{m}^{3}$ of sand and gravel are globally mined every year (Steinberg et al., 2010), 551 and the extraction rate is increasing (Krausmann et al., 2009). During the last decade, the total 552 quantity of marine sand and gravel extracted has increased significantly due to more restrictions of the extraction of aggregate from terrestrial sources. Furthermore, the rate of offshore extraction is expected to further increase in the coming years for coastal protection as a measure to counteract sea level rise.

In Europe, most dredging is carried out in northwestern coastal countries where around 50 million $\mathrm{m}^{3}$ of sand and gravel are extracted each year from the inner continental shelf (Sutton and Boyd, 2009). The Netherlands uses around 13 million $\mathrm{m}^{3}$ every year for coastal nourishments. In Spain, there is a strict regulation of aggregate extraction activities, which prohibit the use of marine sand and gravel from the continental shelf for purposes other than beach nourishment. Along the Spanish Mediterranean coast, the beach nourishment programs started in 1983 and continue nowadays. Only between 1997 and 2002, a total fill volume of about 110 millions of $\mathrm{m}^{3}$ was used for coastal protection (Hamm et al., 2002; Hanson et al., 2002). Particularly in the Valencia region, coastal erosion since the 1950 s was estimated at 3 million $\mathrm{m}^{3} /$ year and is expected to rise over the coming years due to expanding urban development and extensive tourism (Yepes and Medina, 2005). In order to stabilize these coastal sectors and to maintain their environmental and economic value, some 2 million $\mathrm{m}^{3}$ of sand are required each year. The main problem here is that potential marine sand resources are reduced to just one deposit of 20 million $\mathrm{m}^{3}$ of sand located on the inner shelf.

This situation has led to the need to identify new strategic resources with high quality of sand in the middle and outer continental shelf. The quality of a sand reservoir depends on a range of parameters including the sand/mud relation, the content of medium and coarse sand, and the thickness of the surficial mud layer. In the Valencia sand ridge field, it was defined a potential sand deposit based on the following criteria: a surficial mud content lower than $50 \%$ or a surficial mud layer thinner than $0.5 \mathrm{~m}$, a sediment layer thicker than $1.5 \mathrm{~m}$ and a medium to coarse sand content higher than $60 \%$ (Fig. 13). The uppermost limit of this deposit corresponds 
577

578

579

580

581

582

583

584

585

586

588

589

591

592

595

597

to the present seafloor. The lowermost limit is defined by the coarse-grained layer that corresponds to the basal reflector, or the maximum depth of the vibrocores, where they do not penetrate the underlying coarse lag. On this basis, the total surface of the potential borrow areas is about $8 \cdot 10^{6} \mathrm{~m}^{2}$. The potential reservoir has a minimum volume of $35 \cdot 10^{6} \mathrm{~m}^{3}$, of which $22 \cdot 10^{6}$ $\mathrm{m}^{3}$ corresponds to relatively well-sorted medium and coarse sand, $7.510^{6} \mathrm{~m}^{3}$ of gravel and $5.5 \cdot 10^{6} \mathrm{~m}^{3}$ of mud.

This sedimentary deposit constitutes a valuable potential sand resource because of the high quality of sediment. However, given the level of demand of the region, the stored volume of sand would only cover the nourishment requirements for recreational and protection purposes of the region for about 7 years. Furthermore, it is expected that accelerate sea level rise caused by global warming in the next decades will increase the demand of sand for beach stabilization purposes. While knowledge of sand ridges is required for the evaluation of the non-renewable strategic mineral resources of the continental shelf, their exploitation must be carefully evaluated following criteria of sustainability and ecological and environmental impact. On that basis, even though the sand ridges on the Valencia outer shelf constitute a finite resource and represent a strategic potential as a sand borrow area, the sand sediment availability in GoV sand ridges is insufficient for a medium-term coastal management strategy based on beach nourishments and it should be discouraged. However, a limited exploitation to avoid the shortterm depletion of the sand deposit could be justified as a complementary action in a general coastal adaptation strategy for the next decades.

\section{CONCLUSIONS}

The detailed sedimentological characterization of the GoV sand ridges provides valuable information about the formation and long-term evolution of offshore sand ridges on tideless continental shelves.

Sand ridges develop over an irregular erosion surface, mantled with coarse sand with pebbles 
602 and cobbles, that locally crops out at the seafloor in some troughs between the ridges and is 603 interpreted as the Holocene wave ravinement surface. Small topographic irregularities of this 604 surface are related to shoreline-associated features that may act as the precursor for sand ridge 605 development. Their preservation below the sand ridges could be explained by the hardness of these features that makes them highly resistant to erosion.

The internal architecture and sediment characteristics of the GoV sand ridges provide insights into their migration. Internally, sand ridges are composed of well-sorted sand with interbedded mud layers, as interpreted from dipping internal reflections, indicating periods of reactivation after relatively calm periods dominated by mud deposition during the active phase of the sand 611 ridges.

612 The internal structure of some small sand ridges also provides further insights into their growths 613 and the final stage of evolution of storm-dominated sand ridges that could be used for the 614 identification of ancient isolated marine sand bodies in outcrops and the subsurface. The 615 transition from active to moribund ridges is evidenced by a progressive change from a phase of 616 progradation into a phase of aggradation and finally to the deposition of onlapping finer 617 deposits over flanks and in troughs of the ridges.

618 Although the northernmost sand ridges appear to be at the last stage of their geological 619 evolution, the morphology and sediment characteristics of other sand ridges show no evidences 620 of degradation. Their maintenance would be explained by local hydrodynamics. Active sediment dynamics during storms (currents and even waves and currents) could be contributing to the maintenance of their morphology, preventing their burial by fine sediments. sand reservoir of $22 \cdot 10^{6} \mathrm{~m}^{3}$ of relatively well-sorted medium and coarse sand with a limited mud content. Because of the high quality of this reservoir, the GoV sand ridge field should be considered as a strategic and finite sand reservoir. 


\section{REFERENCES}

Albarracín S, Alcántara-Carrió J, Barranco A, Sánchez García MJ, Fontán Bouzas Á, Rey Salgado J. 2013. Seismic evidence for the preservation of several stacked Pleistocene coastal barrier/lagoon systems on the Gulf of Valencia continental shelf (western Mediterranean). Geo-Marine Letters 33: 217-223.

Albarracín S, Alcántara-Carrió J, Montoya-Montes I, Fontán-Bouzas Á, Somoza L, Amos CL, Salgado JR. 2014. Relict sand waves in the continental shelf of the Gulf of Valencia (Western Mediterranean). Journal of Sea Research 93: 33-46.

Alcántara-Carrió J, Albarracín S, Montoya Montes I, Flor-Blanco G, Fontán Bouzas Á, Rey Salgado J. 2013. An indurated Pleistocene coastal barrier on the inner shelf of the Gulf of Valencia (western Mediterranean): evidence for a prolonged relative sea-level stillstand. Geo-Marine Letters 33: 209-216.

Bassetti M A, Jouet G, Dufois F, Berné S, Rabineau M, Taviani M. 2006. Sand bodies at the shelf edge in the Gulf of Lions (Western Mediterranean): Deglacial history and modern processes. Marine Geology 234: 93-109.

Berné S, Jouet G, Bassetti M A, Dennielou B, Taviani M. 2007. Late Glacial to Preboreal sealevel rise recorded by the Rhône deltaic system (NW Mediterranean). . Marine Geology 245: $65-88$.

Blott S.J., Pye K. 2001. GRADISTAT: a grain size distribution and statistics package for the analysis of unconsolidated sediments. Earth Surface Processes and Landforms 26: 12371248.

Calvete D, Falques A, De Swart HE, Walgreen M. 2001. Modelling the formation of shorefaceconnected sand ridges on storm-dominated inner shelves. Journal of Fluid Mechanics 441: $169-193$.

Cánovas M. 1958. Avenidas motivadas por las lluvias extraordinarias de los días 13 y 14 de octubre de 1957. Revista de Obras Públicas (February): 59-68.

Dalrymple RW, Hoogendoorn EL. 1997. Erosion and deposition on migrating shorefaceattached ridges, Sable Island, eastern Canada. Geosciences Canada 24: 25-36.

De Falco G Antonioli F, Fontolan G, Lo Presti V, Simeone S, Tonielli R. 2015. Early cementation and accommodation space dictate the evolution of an overstepping barrier 
system during the Holocene. Marine Geology 369: 52-66.

de Swart HE, and Hulscher SJMH. 1995. Dynamics of large scale bedforms in coastal seas. In: Nonlinear Dynamics and Pattern Formation in the Natural Environment. Doelman A, van Harten A (Eds). Addison Wesley-Longman, Reading, Mass, pp. 315-331.

Durán R, Guillén J, Simarro G, Ribó M, Puig P, Muñoz A, Palanques A. 2015. Sand ridges in the mid-outer shelf as potential sand borrow areas (NW Mediterranean). In: Proceedings of Coastal Sediments 2015: 1-13.

Durán R, Guillén J, Rivera J, Lobo FJ, Muñoz A, Fernández-Salas LM, Acosta J. 2018. Formation, evolution and present-day activity of offshore sand ridges on a narrow, tideless continental shelf with limited sediment supply. Marine Geology 397: 93-107.

Dyer KR, Huntley DA. 1999. The origin, classification and modelling of sand banks and ridges. Continental Shelf Research 19 (10): 1285-1330.

Emery AR, Hodgson DM, Barlow NLM, Carrivick JL, Cotterill CJ, Mellett CL, Booth AD. 2019. Topographic and hydrodynamic controls on barrier retreat and preservation: An example from Dogger Bank, North Sea. Marine Geology 416: 105981.

Espino M., Sánchez-Arcilla A., García M.A. 1998. Wind induced mesoscale circulation off the Ebro delta, NW Mediterranean: a numerical study. Journal of Marine Systems 16: 235-251.

Figueiredo AG, Sanders JE, Swift DJP. 1982. Storm-graded layers on inner continental shelves: Examples from southern Brazil and the Atlantic coast of the Central United States. Sedimentary Geology 31: 171-190.

Folk RL. 1954. The distinction between grain size and mineral composition in sedimentary-rock nomenclature. Journal of Geology 62:344-359.

Folk RL, Ward WC. 1957. Brazos River bar: a study in the significance of grain size parameters. Journal of Sedimentary Petrology 27:3-26.

Font, J. 1990. A comparison of seasonal winds with currents on the continental slope of the Catalan sea (NW Mediterranean). Journal of Geophysical Research 95: 1537-1545.

Guillén J, Jiménez JA, Palanques A, Gracia V, Puig P, Sánchez-Arcilla A. 2002. Sediment resuspension across a microtidal, low-energy inner shelf. Continental Shelf Research 22: 305-325. Giró S, Maldonado A. 1983. Definición de facies y procesos sedimentarios en la plataforma continental de Valencia (Mediterráneo occidental) In: Castellví, J. (Ed.), Estudio 
oceanográfico de la plataforma continental. Española, Seminario Científico Interdisciplinario, Gráficas Buper, Barc Detailed elona: 75-96.

Goff JA, Orange DL, Mayer LA, Hughes Clarke JE. 1999. Detailed investigation of continental shelf morphology using a high-resolution swath sonar survey: the Eel margin, northern California. Marine Geology 154: 255-269.

Goff JA, Gulick S, Nordfjord S, Christensen B, Sommerfield C, Olson H, Alexander C. 2005. Recent and modern marine erosion on the New Jersey outer shelf. Marine Geology 216: $275-296$.

Goff JA, Duncan LS. 2012. Re-examination of sand ridges on the middle and outer New Jersey shelf based on combined analysis of multibeam bathymetry and backscatter, seafloor grab samples and chirp seismic data. Int. Assoc. Sedimentology Special Publications. 44: 121142.

Goff JA. 2014. Seismic and core investigation off Panama city, Florida, reveals sand ridge influence on formation of the shoreface ravinement. Continental Shelf Research 88: 34-46. Green AN, Cooper JAG, Leuci R, Thackeray Z. 2013. Formation and preservation of an overstepped segmented lagoon complex on a high-energy continental shelf. Sedimentology 60: $1755-1768$.

Guerrero Q, Guillén J, Durán R, Urgeles R. 2018. Contemporary genesis of sand ridges in a tideless erosional shoreface. Marine Geology 395: 219-233.

Hamm L, Capobianco M, Dette HH, Lechuga A, Spanhoff R, Stive MJF. 2002. A summary of European experience with shore nourishment. Coastal Engineering 47: 237-264.

Hanson H, Brampton A, Capobianco M, Dette HH, Hamm L, Laustrup C, Lechuga A, Spanhoff R. 2002. Beach nourishment projects, practices and objectives-a European overview. Coastal Engineering 47: 81-111.

Hulscher S. J. M. H., de Swart H. E., de Vriend H. J. 1983. The generation of offshore tidal sand banks and sand waves. Continental Shelf Research 13: 1183-1204.

Huthnance JM. 1982. On one mechanism forming linear sand banks. Estuarine Coastal and Shelf Science. 14: 79-99.

King CAM, Williams WW. 1949. The Formation and Movement of Sand Bars by Wave Action. The Geographical Journal 113: 70-85.Krause F and Nelson DA. 1991. Evolution of an 

Upper Cretaceous (Turonian) shelf sandstone ridge in the Cardium Formation, Pembina area, west-central Alberta, Canada. In: Shelf Sand and Sandstone Bodies: Geometry, Facies and Sequence Stratigraphy (Eds D.J.P. Swift, G.F. Oertel, R.W. Tillman and J.A. Thorne), Int. Assoc. Sedimentology Special Publications 14: 427-456.

Krausmann F, Gingrich S, Eisenmenger N, Erb KH, Haberl H, Fischer-Kowalski M. 2009. Growth in Global Materials Use, GDP and Population during the 20th Century. Ecological Economics 68: 2696-2705.

Leva-López JL, Rossi VM, Olariu C, Steel RJ. 2016. Architecture and recognition criteria of ancient shelf ridges; an example from Campanian Almond Formation in Hanna Basin, USA. Sedimentology 63: 1651-1676.

Li MZ, King EL. 2007. Multibeam bathymetric investigations of the morphology of sand ridges and associated bedforms and their relation to storm processes, Sable Island Bank, Scotian Shelf. Marine Geology 243: 200-228.

Liu $\mathrm{Z}$ et al. 2007. Internal architecture and mobility of tidal sand ridges in the East China Sea. Continental Shelf Research 27: 1820-1834.

Lo Iacono C, Guillén J, Puig P, Ribó M, Ballesteros M, Palanques A, lí Farrán M, Acosta J. 2010. Large-scale bedforms along a tideless outer shelf setting in the western Mediterranean.

Lobo FJ, Durán R, Roque C, Ribó M, Carrara G, Mendes I, Ferrín A. 2015. Shelves around the Iberian Peninsula (II): Evolutionary sedimentary patterns. 126: 377-408.

Lobo FJ, García M, Luján M, Mendes I, Reguera MI, Van Rooij D. 2018. Morphology of the last subaerial unconformity on a shelf: insights into transgressive ravinement and incised valley occurrence in the Gulf of Cádiz. Geo-Marine Letters 38: 33-45.

Maldonado A, Swift DJP, Young RA, Han G, Nittrouer CA, DeMaster DS, Rey J, Palomo C, Acosta J, Ballester A, Castellvi J. 1983. Sedimentation on the Valencia Continental Shelf: preliminary results. Continental Shelf Research 2: 195-211.

Martín- Vide X. 1985. Pluges i inundacions a la Mediterrània, Barcelona, Ketres, 132 pp. 
McBride RA, Moslow TF. 1991. Origin, evolution and distribution of shoreface sand ridges, Atlantic inner shelf, U.S.A. Marine Geology 97: 57-85.

McHugh CM, Hartin CA, Mountain GS, Gould HM. 2010. The role of glacio-eustasy in sequence formation: Mid-Atlantic Continental Margin, USA. Marine Geology 277: 31-47.

Mellett CL, Hodgson DM, Lang A, Mauz B, Selby I, Plater AJ. 2012. Preservation of a drowned gravel barrier complex: A landscape evolution study from the north-eastern English Channel. Marine Geology 315-318: 115-131.

Mellett CL, Plater AJ. 2018. Drowned Barriers as Archives of Coastal-Response to Sea-Level Rise. In Barrier Dynamics and Response to Changing Climate. Moore LJ and Murray AB (Eds). Springer International Publishing: Cham; 57-89.

Nnafie A, de Swart HE, Calvete D, Garnier R. 2014. Effects of sea level rise on the formation and drowning of shoreface-connected sand ridges, a model study. Continental Shelf Research 80: 32-48.

Palanques A, Puig P, Guillén J, Jiménez J, Gracia V, Sánchez-Arcilla A, Madsen O. 2002. Near-bottom suspended sediment fluxes on the microtidal low-energy Ebro continental shelf (NW Mediterranean). Continental Shelf Research 22: 285-303.

Pretorius L, Green A, Cooper A. 2016. Submerged shoreline preservation and ravinement during rapid postglacial sea-level rise and subsequent lowstand. Geological Society of America Bulletin 128: 1059-1069.

Puig P, Palanques A, Guillén J. 2001. Near-bottom suspended sediment variability caused by storms and near-inertial internal waves on the Ebro mid continental shelf (NW Mediterranean). Marine Geology 178: 81-93.

Reesink AJH, Bridge JS. 2007. Influence of superimposed bedforms and flow unsteadiness on formation of cross strata in dunes and unit bars: Sedimentary Geology 202: 281-296.

Rey J, Díaz del Río V. 1983. Aspectos geológicos sobre la estructura poco profunda de la plataforma del Levante Español. In: Castellví J (ed) Estudio oceanográfico de la plataforma continental. Sem Interdisc Hispanic-American Cooperative Research Project. Gráficas Buper, Barcelona, pp 25-83

Rey J, Fernández-Salas LM, Blázquez AM. 1999. Identificación de las unidades morfosedimentarias cuaternarias en la plataforma interna del litoral del País Valenciano: el 
rol de los factores morfoestructurales y eustáticos. In Geoarqueologia Quaternari litoral. Memorial M.P. Fumanal: 403-418.

Ribó, M., Goodwin, I. D., O’Brien, P., Mortlock, T. in press. Shelf sand supply determined by glacial-age sea-level modes, submerged coastlines and wave climate. Scientific Reports.

Robinson MM, McBride RA. 2006. Benthic foraminifera from a relict flood tidal delta along the Virginia/North Carolina Outer Banks. Micropaleontology 52: 67-80.

Salat J. 1995. The interaction between the Catalan and Balearic currents in the southern Catalan Sea Oceanological Acta 18: 227-234.

Salat J, Garcia M, Cruzado A, Palanques A, Arín L, Gomis D, Guillén J, de León A, Puigdefäbregas J, Sospedra J, Velásquez Z. 2002. Seasonal changes of water mass structure and shef slope exchanges at the Ebro Shelf (NW Mediterranean). Continental Shelf Research $22,327-348$.

Salzmann L, Green A, Cooper JAG. 2013. Submerged barrier shoreline sequences on a high energy, steep and narrow shelf. Marine Geology 346: 366-374.

Sanjaume, E., Rosselló V.M., Pardo J.E., Carmona P., Segura F,m López García M.J. 1996. Recent coastal changes inth e Gulf of Valencia (Spain). Z. Geomorph. N.F. 102: 95-112.

Schwab WC, Baldwin WE, Hapke CJ, Lentz EE, Gayes PT, Denny JF, List JH, Warner JC. 2013. Geologic Evidence for Onshore Sediment Transport from the Inner Continental Shelf: Fire Island, New York. Journal of Coastal Research 29 (3): 526-544.

Schwab WC, Baldwin WE, Denny JF, Hapke CJ, Gayes PT, List JH, Warner JC. 2014. Modification of the Quaternary stratigraphic framework of the inner-continental shelf by Holocene marine transgression: an example offshore of Fire Island, New York. Marine Geology 355: 346-360.

Schwarz E. 2012. Sharp-based marine sandstone bodies in the Mulichinco Formation (Lower Cretaceous), Neuquén Basin, Argentina: Remnants of transgressive offshore sand ridges. Sedimentology 59: 1478-1508.

Simarro G, Guillén J, Puig P, Ribó M, Lo Iacono C, Palanques A, Muñoz A Durán R, Acosta J. 2015. Sediment dynamics over sand ridges on a tideless mid-outer continental shelf. Marine Geology 361: 25-40.

Snedden JW, Kreisa RD, Tillman RW, Scheweller WJ, Culver SJ, Winn RD. 1994. Stratigraphy 
and genesis of a modern shoreface-attached sand ridge, Peahala Ridge, New Jersey. Journal of Sedimentary Research 119: 175-199.

Snedden, J.W., Dalrymple, R.W., 1999. Modern shelf sand ridges: From historical perspective to a unified hydrodynamic and evolutionary model. SEPM Concepts in Sedimentolology and Paleontology 6: 13-18.

Snedden JW, Kreisa, RD, Tillman RW, Culver SJ, Schweller WJ. 1999. An expanded model for modern shelf sand ridge genesis and evolution on the New Jersey Atlantic shelf. In Isolated Shallow Marine Sand Bodies; Sequence Stratigraphic Analysis and Sedimentologic Interpretation. Bergman, K.M., and Snedden, J.W., (Eds). SEPM, Special Publication 64: $147-163$.

Snedden JW, Tillman RW, Culver SJ. 2011. Genesis and Evolution of a Mid-Shelf, Storm-Built Sand Ridge, New Jersey Continental Shelf, U.S.A. Journal of Sedimentary Research 81:534552.

Steinberger JK, Krausmann F, Eisenmenger N. 2010. Global patterns of materials use: A socioeconomic and geophysical analysis. Ecological Economics 69: 1148-1158.

Stride AH. 1982. Offshore Tidal Sands, Processes and Deposits. Chapman and Hall, London, $222 \mathrm{pp}$.

Sullivan MD, Van Wagoner JC, Jennette DC, Foster ME, Stuart RM, Lovell RW and Pemberton SG. 1997. High resolution sequence stratigraphy and architecture of the Shannon Sandstone, Hartzog Draw Field, Wyoming. Gulf Coast Sec. SEPM, 18th Annual Research Conference: 331-344.

Suter JR. 2006. Facies models revisited: clastic shelves. In: Posamentier HW, Walker RG (eds) Facies models revisited. SEPM Special Publications 84: 339-397

Sutton G, Boyd S. 2009. Effects of Extraction of Marine Sediments on the Marine Environment 1998 - 2004. ICES Cooperative Research Report 297, 180 pp.

Swift D, Field M. 1981. Evolution of a classic sand ridge field : Maryland sector, North American inner shelf. Sedimentology: 461-482.

Swift DJP, Kofoed JW, Saulsbury FP, Sears,P. 1972. Holocene evolution of shelf surface, central and southern Atlantic Shelf of North America, in Swift, D.J.P., Duane, D.B., and Pilkey, O.H., eds., Shelf Sediment Transport; Process and Pattern: Stroudsburg, 
Pennsylvania, Dowden, Hutchison and Ross, p. 447-498.

Tesson M, Posamentier H, Gensous B. 2015. Compound incised-valley characterization by high-resolution seismics in a wave-dominated setting: Example of the Aude and Orb rivers, Languedoc inner shelf, Gulf of Lion, France. Marine Geology 367: 1-21.

Tillman RW, Martinsen RS. 1984. The Shannon shelfridge sandstone complex, Salt Creek anticline area, Powder River Basin Wyoming. In: Siliciclastic Shelf Sediments (Eds R.W. Tillman and C.T. Siemers), SEPM Special Publications 34: 85-142.

Trowbridge JH. 1995. A mechanism for the formation and maintenance of shore-oblique sand ridges on storm-dominated shelves. Journal of Geophysical Research 100: 16071-16086.

Van de Meene JWH, Van Rijn LC, 1994. Tide- and storm driven sediment transport on the inner-shelf along the Dutch coast. Proceedings Coastal Dynamics'94. ASCE, New York, pp. $822-836$.

Walker RG, Bergman KM. 1993. Shannon Sandstone in Wyoming; a shelf-ridge complex reinterpreted as lowstand shoreface deposits. Journal of Sedimentary Resarch 63: 839-851.

Weiss A. 2001. Topographic position and landforms analysis - Poster Conference. ESRI User Conference, San Diego, CA 64 : 227-245.

Yang C-S. 1989. Active, moribund and buried tidal sand ridges in the East China Sea and the Southern Yellow Sea. Marine Geology 88: 97-116.

Yepes V, Medina JR. 2005. Land use tourism models in Spanish coastal areas. A case study of the Valencia region. Journal of Coastal Research 49: 83-88.

Young RA, Swift DJP, Nittrouer CA, Demaster DJ, Bergenback B. 1983. Event dominated sediment transport on the Valencian continental shelf, Spain, and its effect on sediment accumulation and Holocene stratigraphy. In: Castellví, J. (Ed.), Estudio oceanográfico de la plataforma continental Española. Sem Interdisc Hispanic- American Cooperative Research Project. Gráficas Buper, Barcelona, pp. 1-13.

Zimmerman JTF. 1981. Dynamics, diffusion and geomorphological significance of tidal residual eddies. Nature 290: 549-555. 
866 Figure 1. (a) Location and shaded relief bathymetric map of the Gulf of Valencia margin. (b)

867 Surficial sediment distribution over the continental shelf. Modified from IGME (2005).

868 Locations of Figures 2, 3 and 4 are also shown.

869 Figure 2. (a) Bathymetry of the sand ridges. Individual sand ridges located along the seismic reflection profile are named as ridges I to XI. (b) Shaded relief map showing the location of the 1983 and 2011 seismic profiles and vibrocores. Locations of Figures 3 and 4 are shown.

Figure 3. High-resolution seismic reflection profile across the GoV continental shelf. Highrelief pinnacles in the inner shelf are interpreted as beachrocks (Alcántara-Carrió et al., 2013). See Figures 1and $2 b$ for location.

Figure 4. (a) Uninterpreted and (b) interpreted parametric sub-bottom seismic profile across the sand ridges. (c) Description of co-located (or nearly so) sediment cores. Projected cores are located at a distance shorter than $150 \mathrm{~m}$ from the seismic line. The basal reflector was used as a datum to hang the grain-size trends from the sediment cores. See Figure 2 for location.

Figure 5. Parametric sub-bottom seismic profiles showing reflection amplitudes of two small sand ridges (ridges $I X$ and $X I$ ): amplitudes; (c) and (d) interpreted profiles. (e) Description of the sediment core located on sand ridge IX showed in Fig. 5c. See Figure 4 for location.

883 Figure 6. Grain-size distributions of sediment, composing: (a) the surficial mud layer (VC 48);

884 (b) the interbedded mud layers in the sand ridges (VC 10); (c) the surficial layer of mixed sediment (sand and mud) in the sand ridges (VC 72); (d) the sand ridges sandy layer (VC 114); (e) the poorly sorted sediment facies below the basal surface of the sand ridges (VC 193); (f) the well-sorted fine sand facies below the basal surface of the sand ridges (VC 275); and (g) the coarse lag (VC 18). Locations of samples in the sediment cores are shown in Figures 9 and 10.

\footnotetext{
Figure 7. Core photograph showing the coarse lag.
} 
890 Figure 8. (a) Surficial grain-size distribution based on the Folk classification (Folk, 1954, 891 1974): G, gravel; g, gravelly; (g) slightly gravelly, $S$, sand; s, sandy; $M$, mud; m, muddy. (b) 892 Spatial distribution of the mud content in the surficial sediments. (c) Thickness of the surficial mud layer.

Figure 9. (a) Spatial distribution and (b) main characteristics of Type I sediment cores located on sand ridge crests. (c) Spatial distribution and (d) main characteristics of Type II sediment cores located on the flanks of the sand ridges.

Figure 10. (a) Spatial distribution and (b) main characteristics of Type III sediment cores located in troughs between ridges. (c) Spatial distribution and (d) main characteristics of Type $I V$ sediment cores located in the troughs of the northern sand ridges.

900 Figure 11. (a) Uninterpreted and (b) interpreted parametric sub-bottom seismic profile showing

901 the internal architecture of sand ridge IV. (c) Description of sediment cores. Red lines indicate 902 main discontinuities identified in the seismic profile. Main surfaces identified below the basal 903 reflector are displayed in grey. See Figure 4 for location.

904 Figure 12. Plot of gentle versus steeper flank slopes for the GoV sand ridges. Mean values of 905 shallower and steeper slopes of the ridges observed in the North Atlantic and Mediterranean shelves are included. Modified and updated from Swift and Field (1981).

907 Figure 13. Thickness of sediment layers: (a) sand layer overlying the coarse lag. (b) Spatial 908 distribution of the medium and coarse sand content of the sandy deposits overlying the coarse 909 lag.

\section{ACKNOWLEDGEMENTS}

911 This research was supported by the projects FORMED (CGL2012-33989) and COSTEM

912 (CTM2009-07806). Secretaría General para el Territorio y la Biodiversidad (Ministerio de 913 Agricultura, Alimentación y Medio Ambiente) provided the sedimentary results from

914 vibrocores. R. Durán is supported by the Ocean and Littoral Sedimentary Process Consolidated 
915 Research Group by the Generalitat de Catalunya grant (2017 SGR-863). This manuscript largely

916 benefited from comments of the Editor, Thaiënne van Dijk and David Hodgson. 

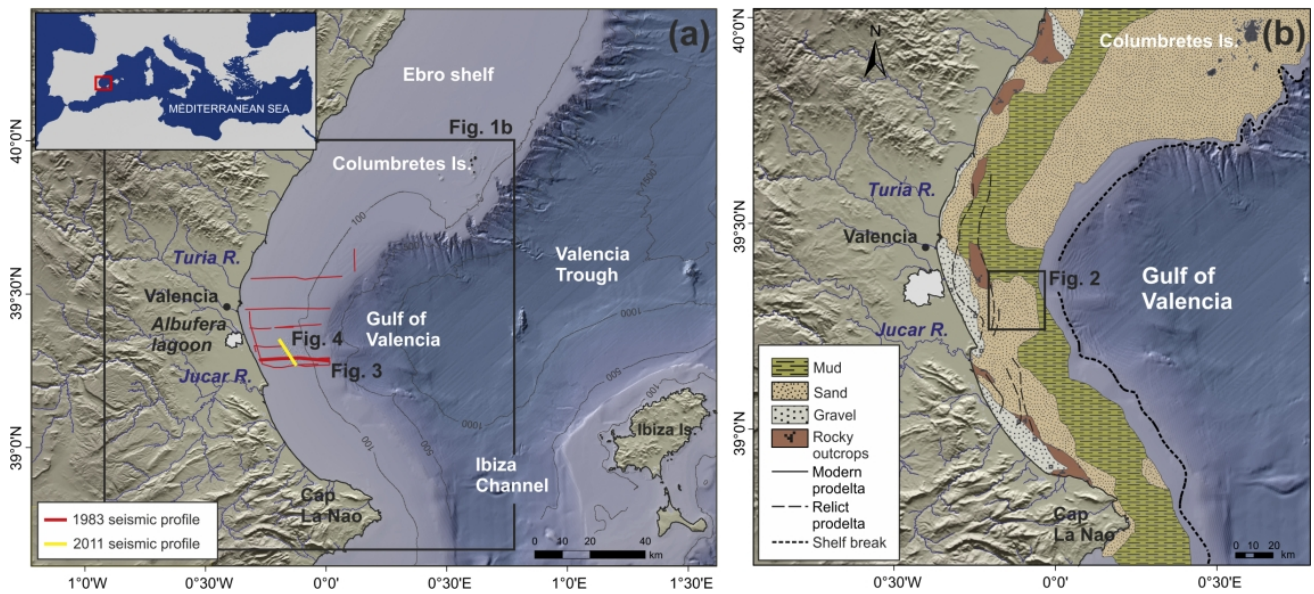

Figure 1. (a) Location and shaded relief bathymetric map of the Gulf of Valencia margin. (b) Surficial sediment distribution over the continental shelf. Modified from IGME (2005). Locations of Figures 2, 3 and 4 are also shown.

$207 \times 92 \mathrm{~mm}(300 \times 300 \mathrm{DPI})$ 

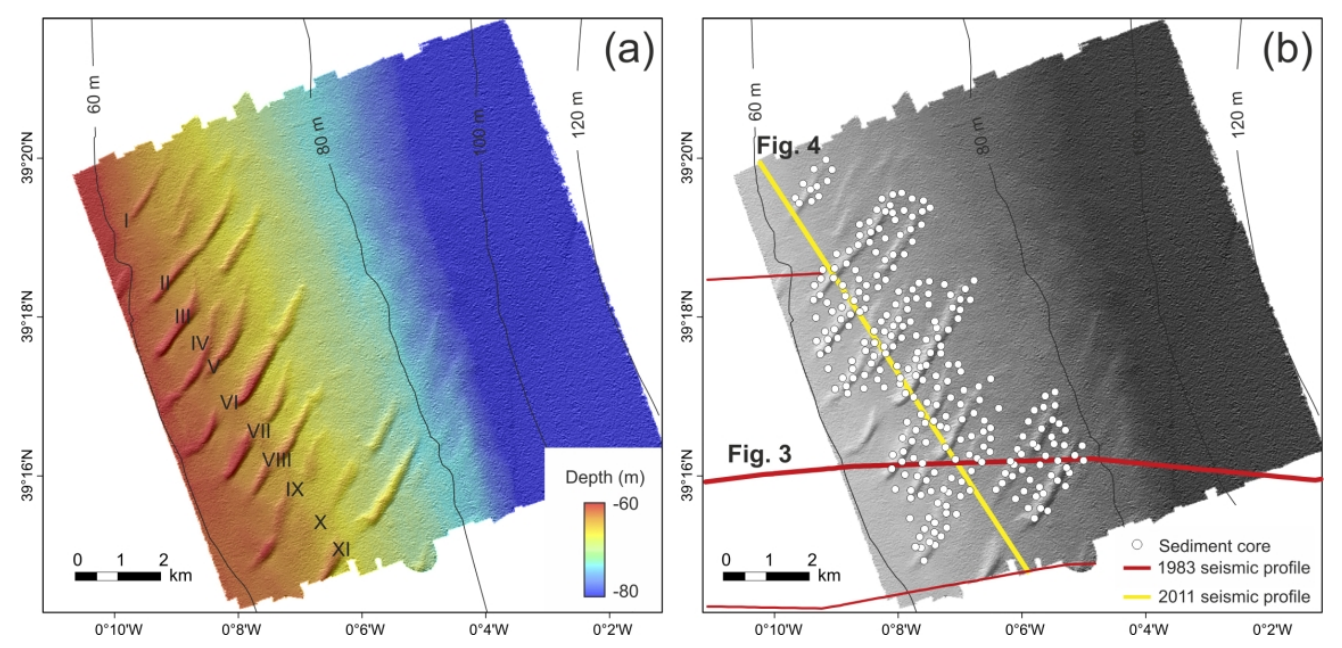

Figure 2. (a) Bathymetry of the sand ridges. Individual sand ridges located along the seismic reflection profile are named as ridges I to XI. (b) Shaded relief map showing the location of the 1983 and 2011 seismic profiles and vibrocores. Locations of Figures 3 and 4 are shown.

$185 \times 87 \mathrm{~mm}(300 \times 300 \mathrm{DPI})$ 


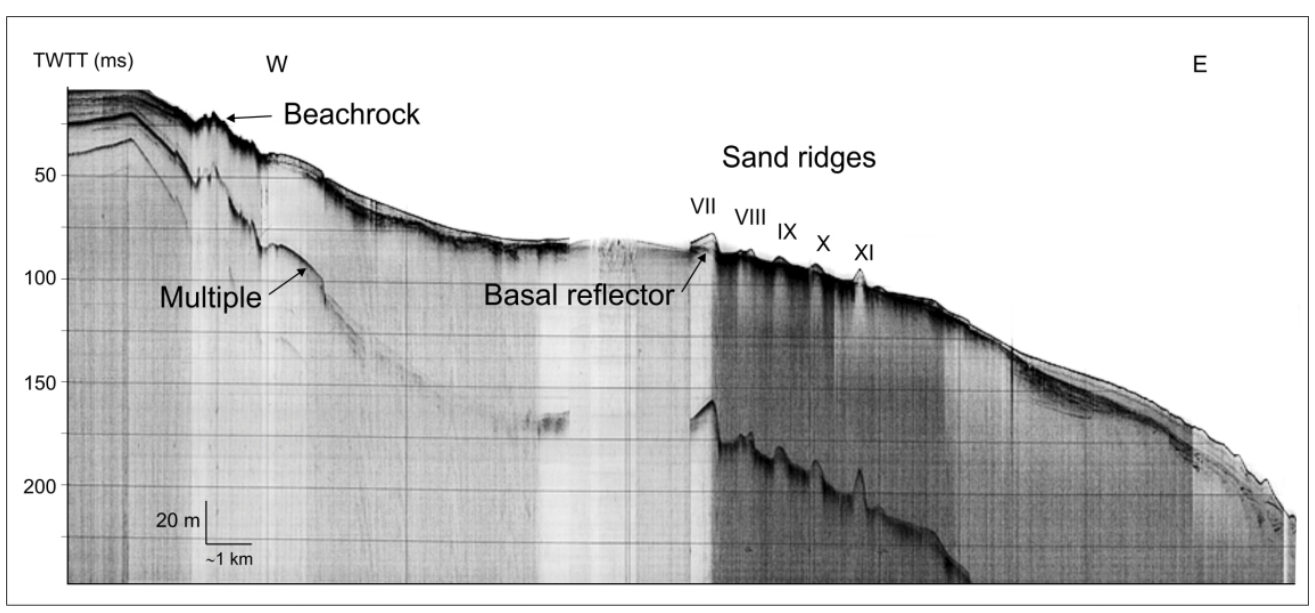

Figure 3. High-resolution seismic reflection profile across the GoV continental shelf. High- relief pinnacles in the inner shelf are interpreted as beachrocks (Alcántara-Carrió et al., 2013). See Figures 1and 2b for location.

$188 \times 85 \mathrm{~mm}(300 \times 300 \mathrm{DPI})$ 

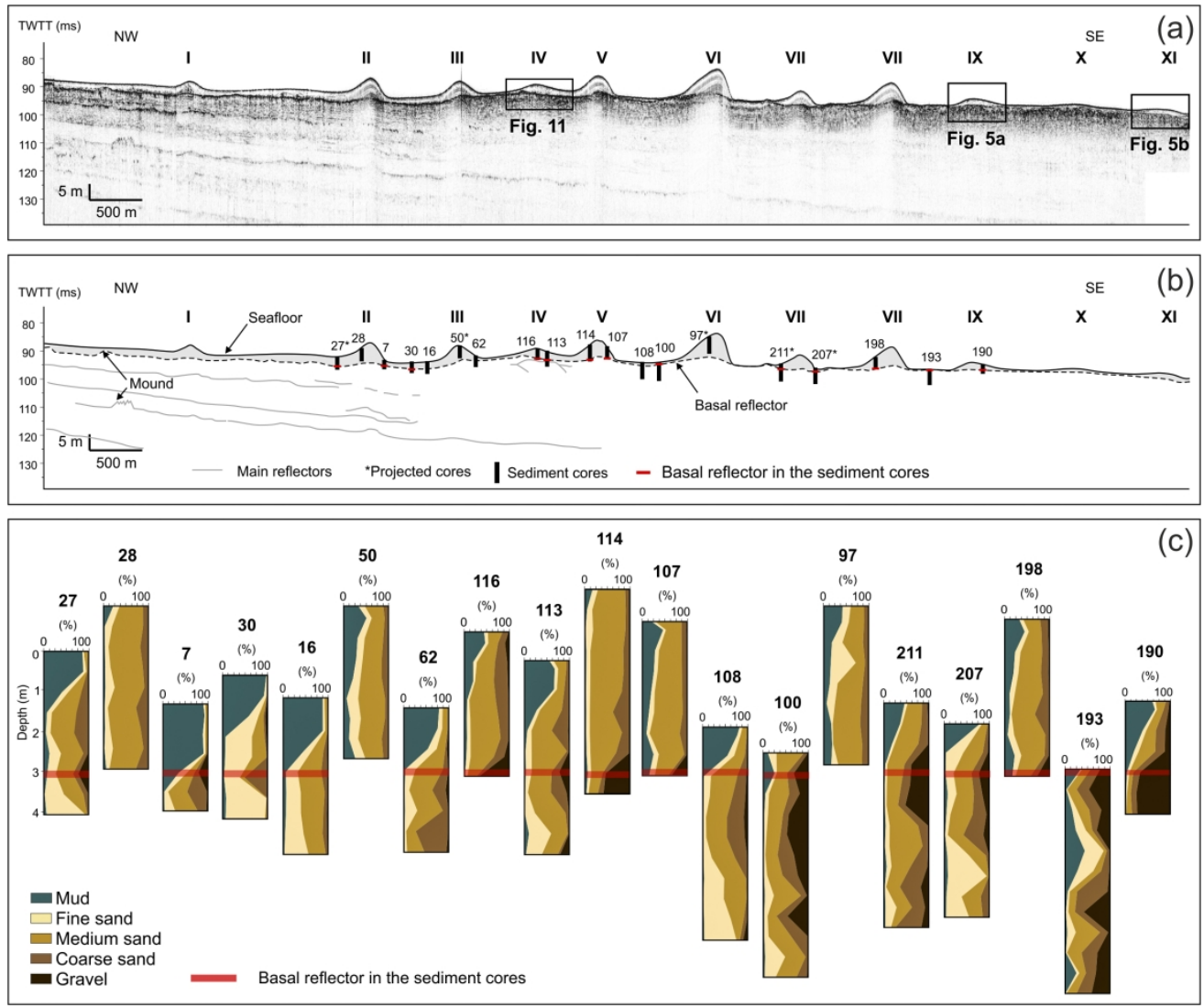

Figure 4. (a) Uninterpreted and (b) interpreted parametric sub-bottom seismic profile across the sand ridges. (c) Description of co-located (or nearly so) sediment cores. Projected cores are located at a distance shorter than $150 \mathrm{~m}$ from the seismic line. The basal reflector was used as a datum to hang the grain-size trends from the sediment cores. See Figure 2 for location.

$203 \times 170 \mathrm{~mm}(300 \times 300$ DPI) 


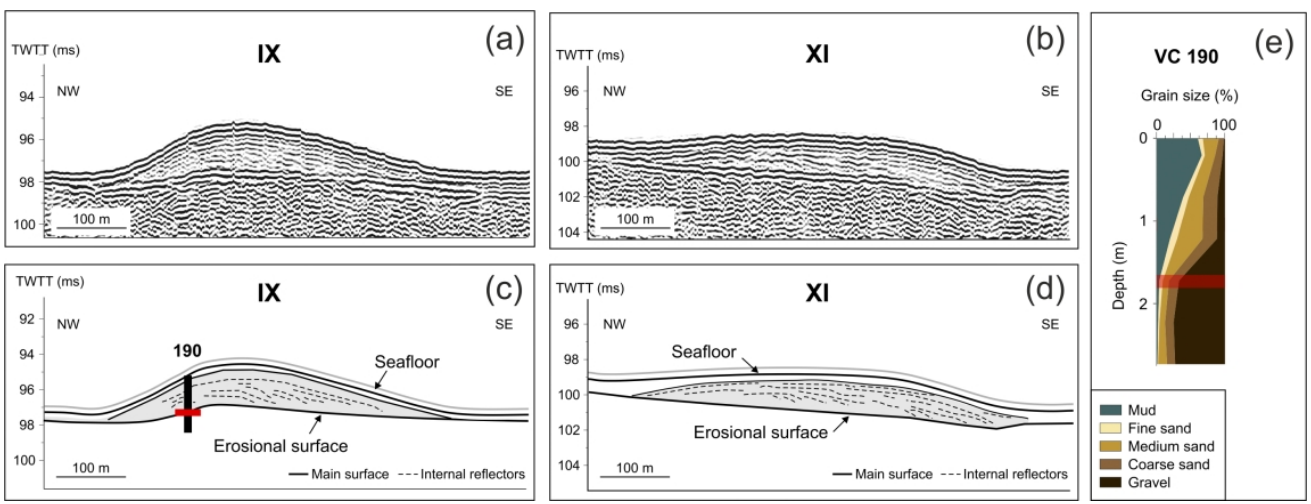

Figure 5. Parametric sub-bottom seismic profiles showing reflection amplitudes of two small sand ridges (ridges IX and XI): (a) and (b) uninterpreted profiles showing reflection amplitudes; (c) and (d) interpreted profiles. (e) Description of the sediment core located on sand ridge IX showed in Fig. 5c. See Figure 4 for location.

$237 \times 89 \mathrm{~mm}(300 \times 300 \mathrm{DPI})$ 


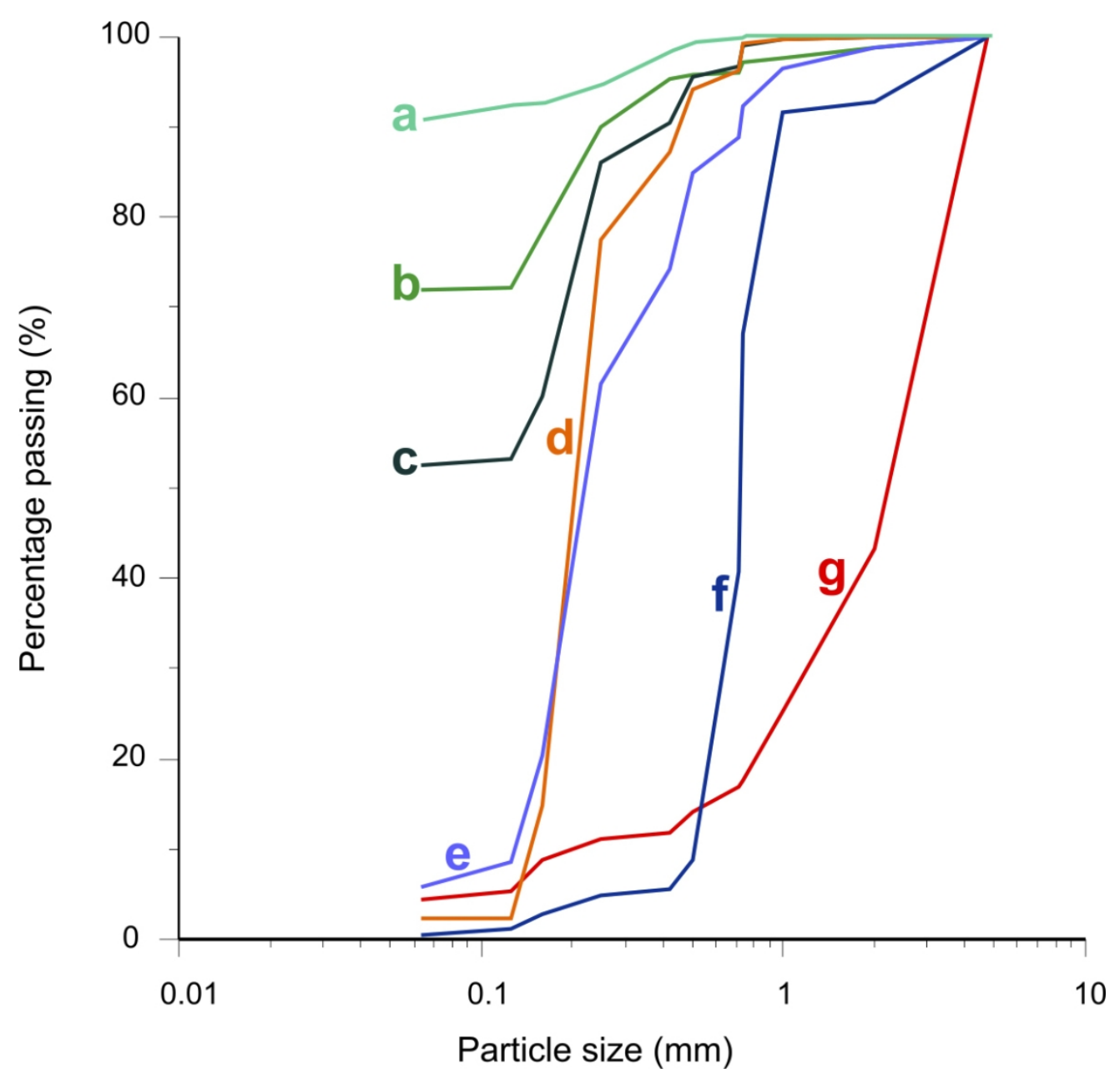

Figure 6. Grain-size distributions of sediment, composing: (a) the surficial mud layer (VC 48); (b) the interbedded mud layers in the sand ridges (VC 10); (c) the surficial layer of mixed sediment (sand and mud) in the sand ridges (VC 72); (d) the sand ridges sandy layer (VC 114); (e) the poorly sorted sediment facies below the basal surface of the sand ridges (VC 193); (f) the well-sorted fine sand facies below the basal surface of the sand ridges (VC 275); and (g) the coarse lag (VC 18). Locations of samples in the sediment cores are shown in Figures 9 and 10.

$99 \times 96 \mathrm{~mm}(300 \times 300 \mathrm{DPI})$ 


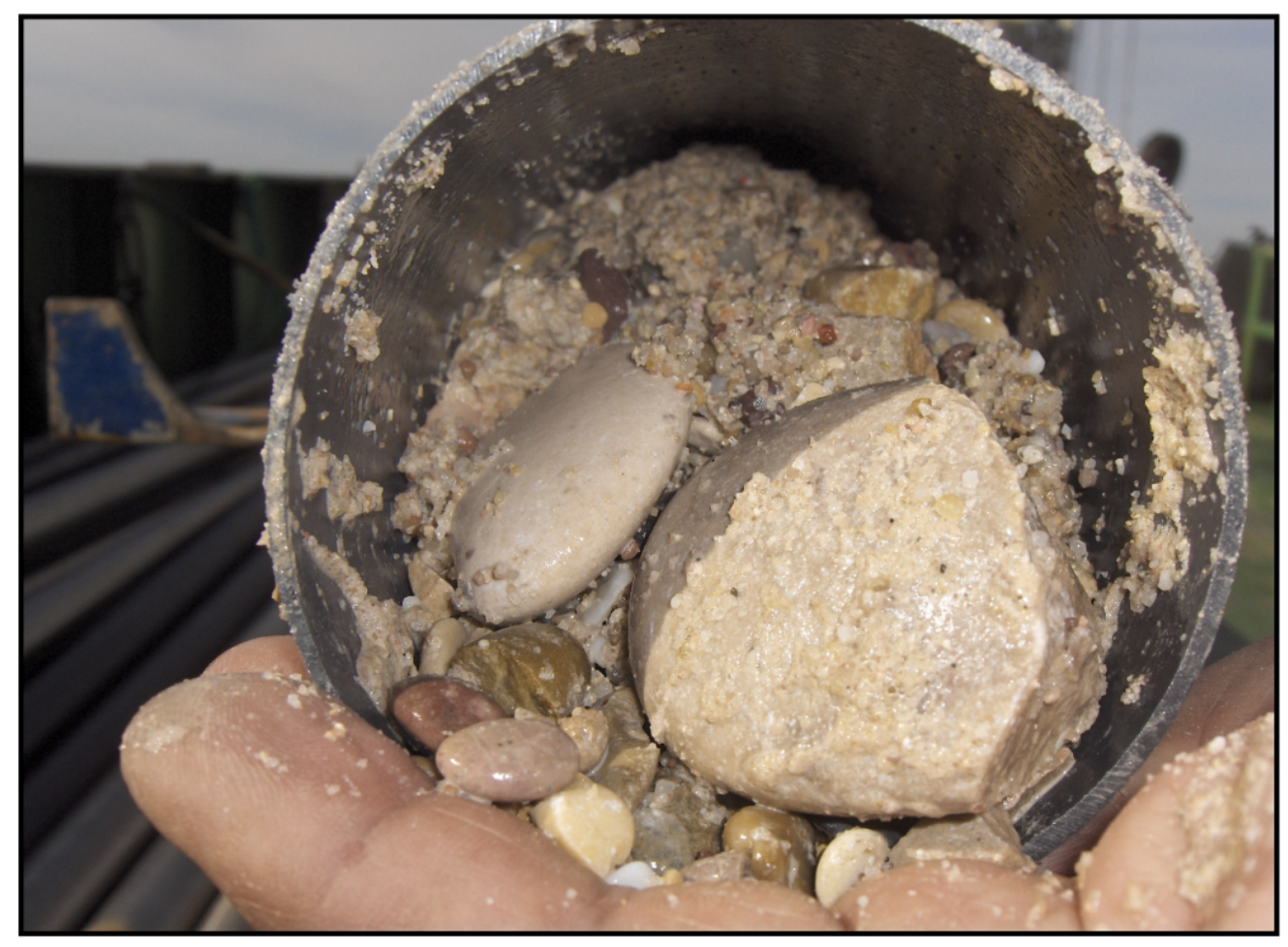

Figure 7. Core photograph showing the coarse lag.

$87 \times 64 \mathrm{~mm}(300 \times 300$ DPI $)$ 

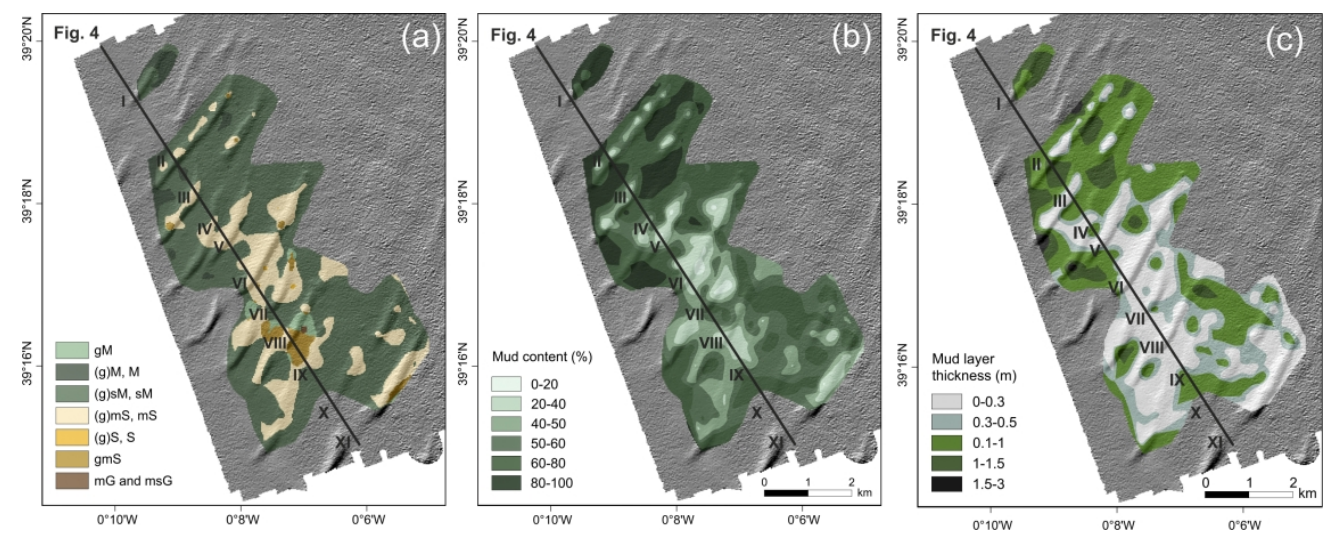

Figure 8. (a) Surficial grain size distribution based on the Folk classification (Folk, 1954, 1974): G, gravel; g, gravelly; (g) slightly gravelly, S, sand; s, sandy; M, mud; m, muddy. (b) Spatial distribution of the mud content in the surficial sediments. (c) Thickness of the surficial mud layer.

$262 \times 103 \mathrm{~mm}(300 \times 300$ DPI) 

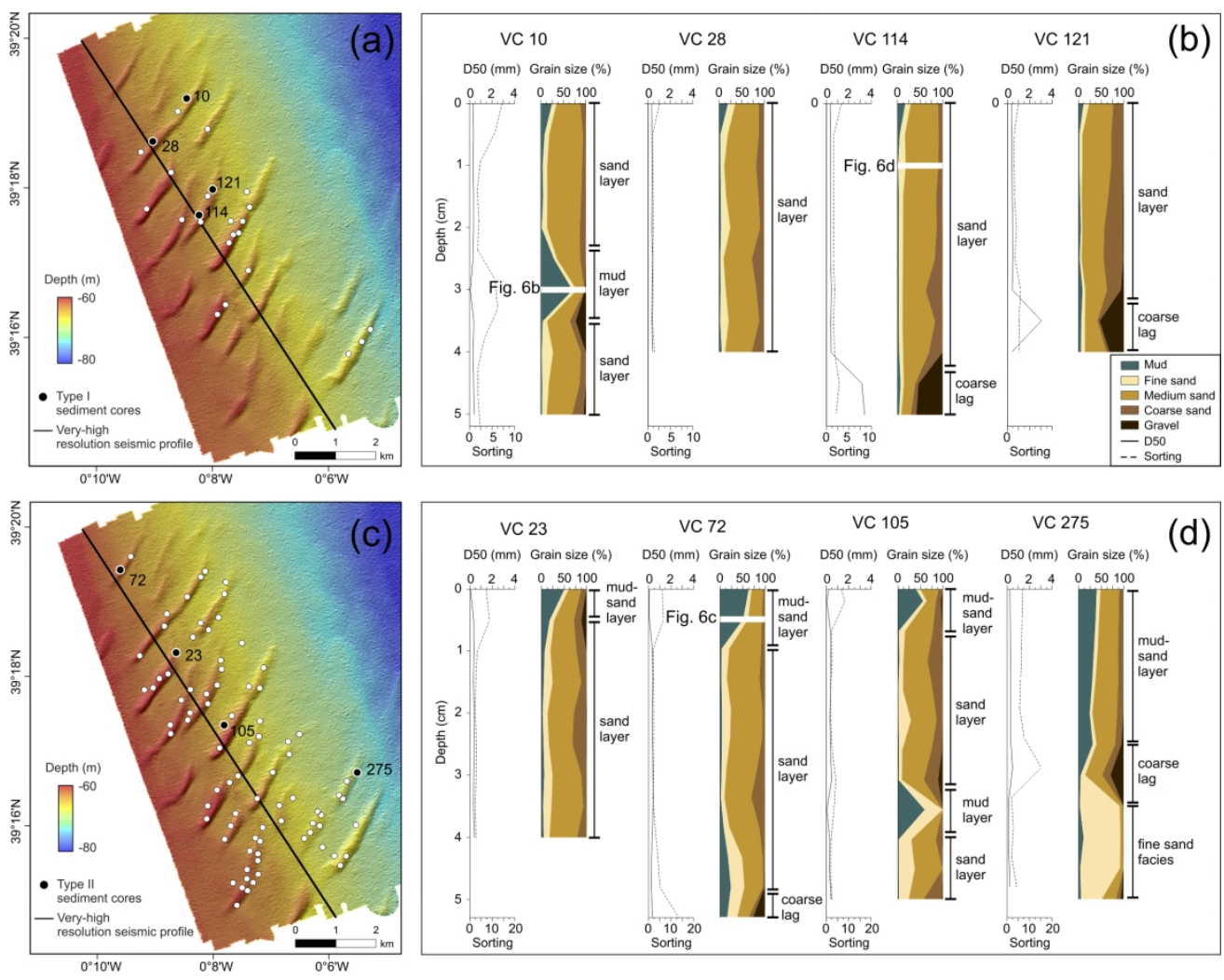

Figure 9. (a) Spatial distribution and (b) main characteristics of Type I sediment cores located on sand ridge crests. (c) Spatial distribution and (d) main characteristics of Type II sediment cores located on the flanks of the sand ridges.

$201 \times 159 \mathrm{~mm}(300 \times 300 \mathrm{DPI})$ 

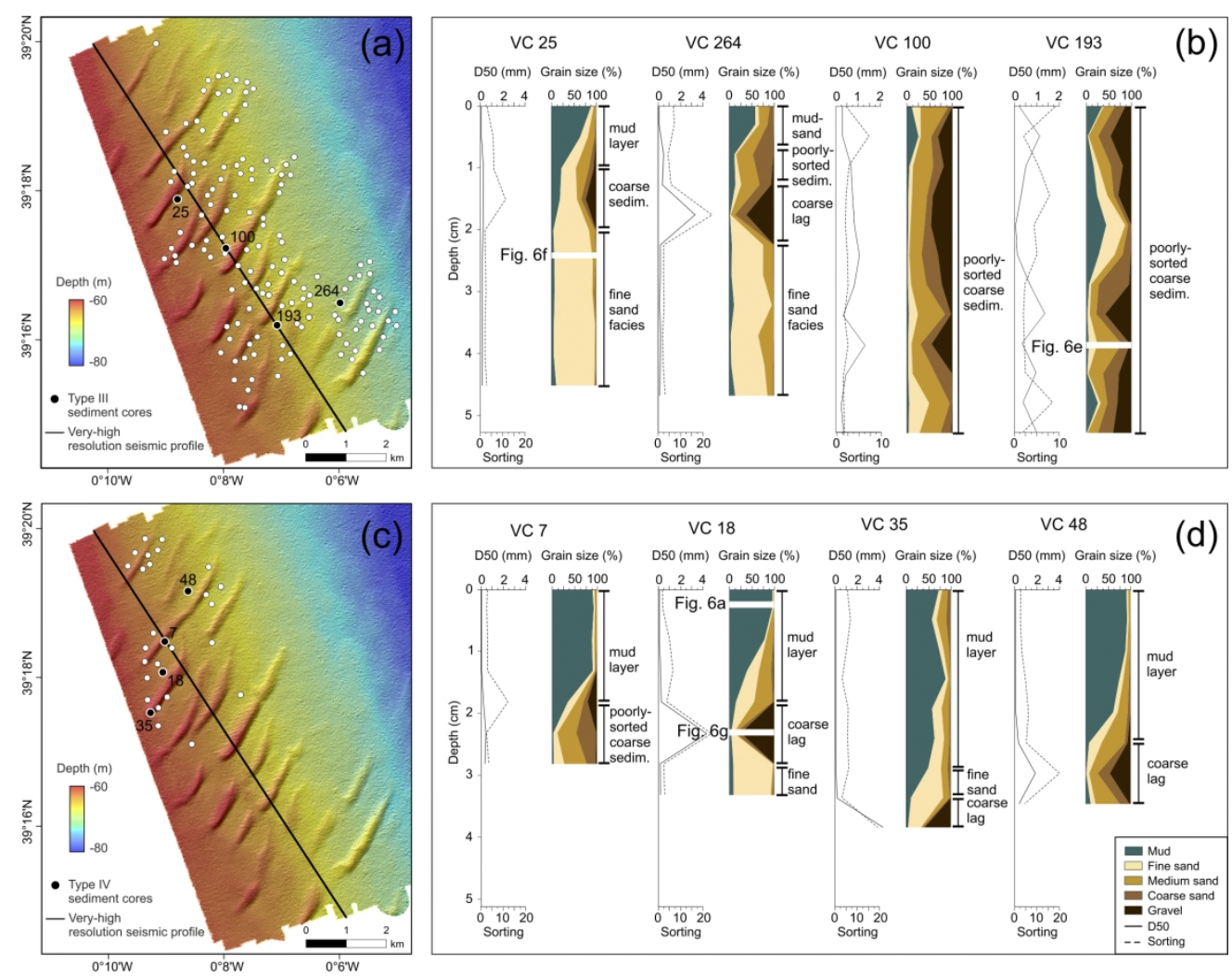

Figure 10. (a) Spatial distribution and (b) main characteristics of Type III sediment cores located in troughs between ridges. (c) Spatial distribution and (d) main characteristics of Type IV sediment cores located in the troughs of the northern sand ridges.

$201 \times 159 \mathrm{~mm}(300 \times 300$ DPI) 


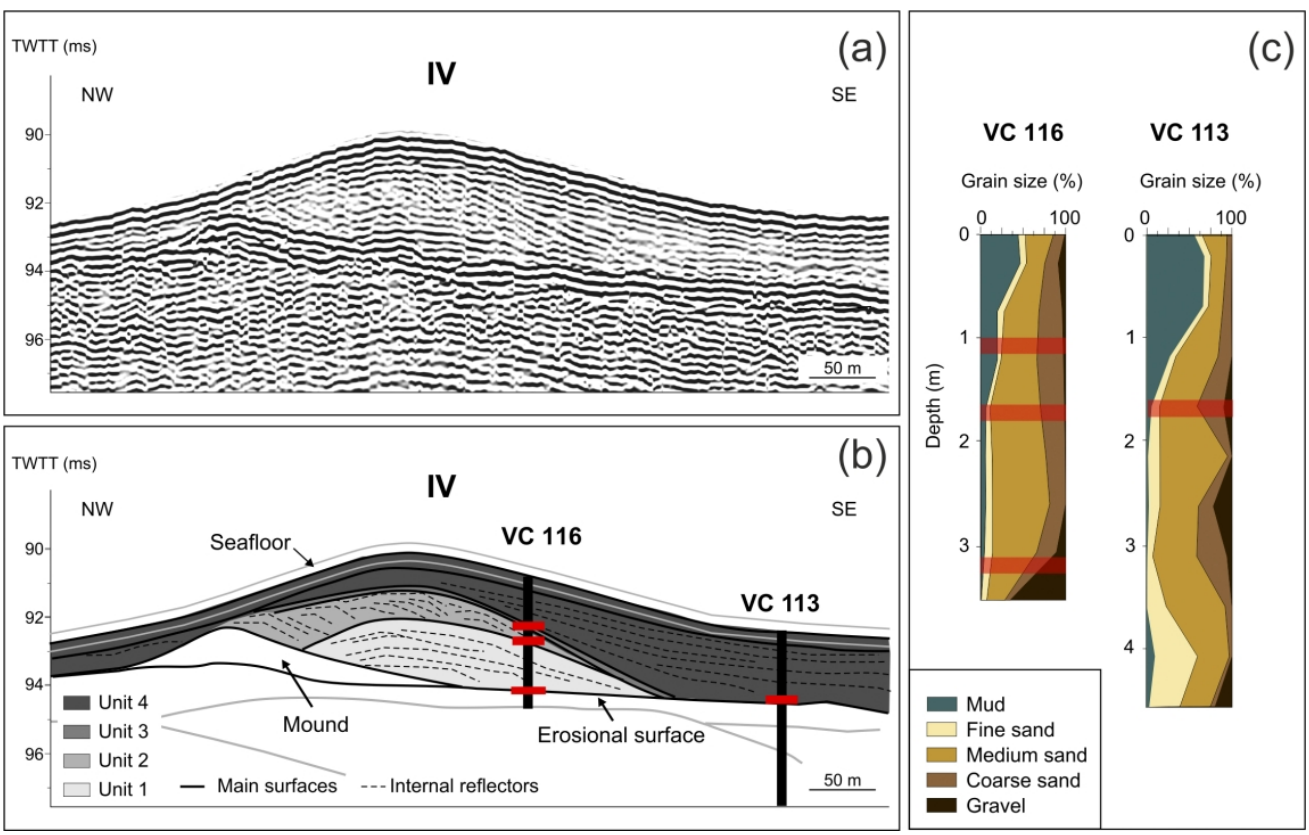

Figure 11. (a) Uninterpreted and (b) interpreted parametric sub-bottom seismic profile showing the internal architecture of sand ridge IV. (c) Description of sediment cores. Red lines indicate main discontinuities identified in the seismic profile. Main surfaces identified below the basal reflector are displayed in grey. See Figure 4 for location.

$190 \times 119 \mathrm{~mm}(300 \times 300 \mathrm{DPI})$ 


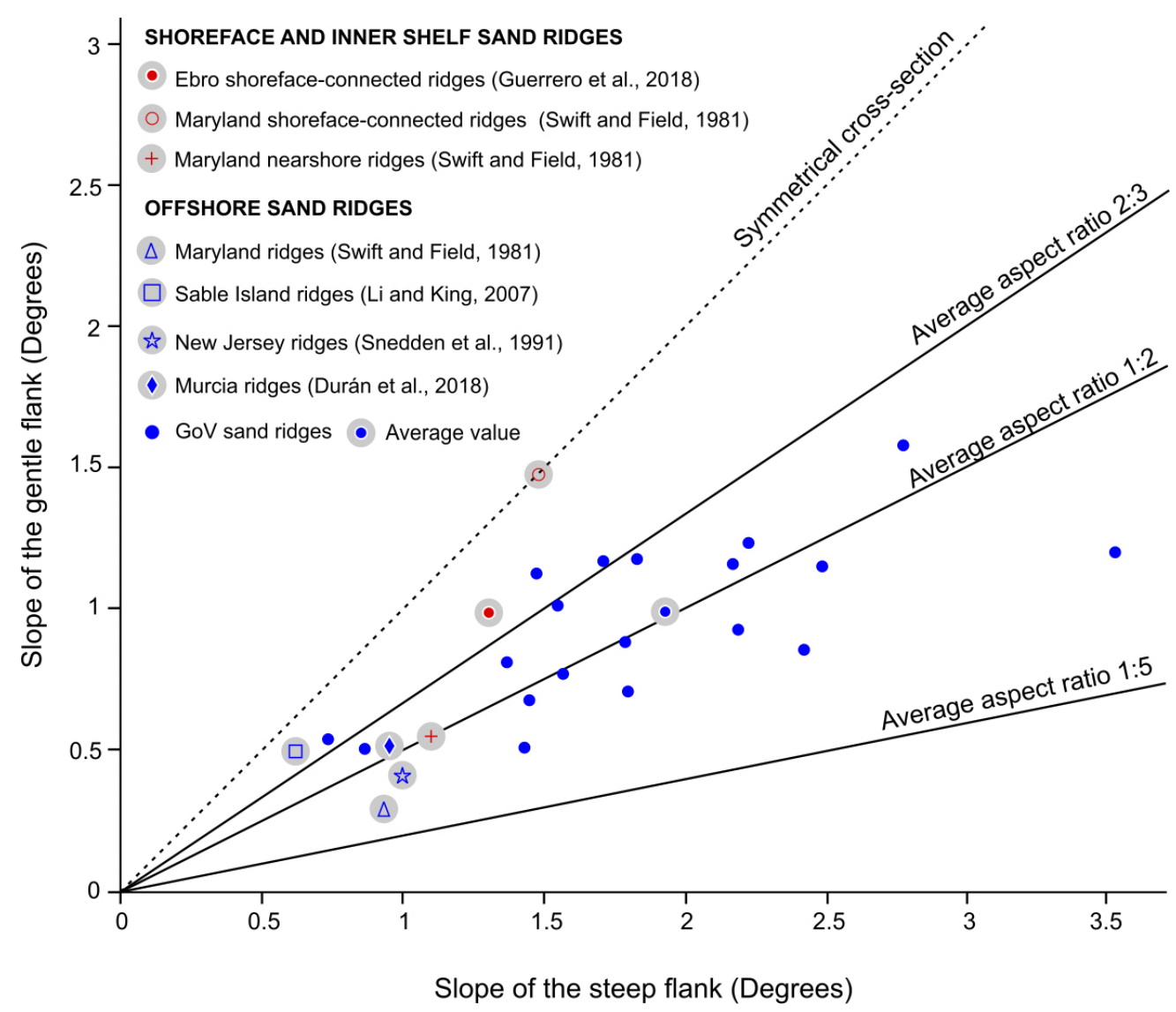

Figure 12. Plot of gentle versus steeper flank slopes for the GoV sand ridges. Mean values of shallower and steeper slopes of the ridges observed in the North Atlantic and Mediterranean shelves are included. Modified and updated from Swift and Field (1981).

$$
102 \times 88 \mathrm{~mm}(300 \times 300 \mathrm{DPI})
$$



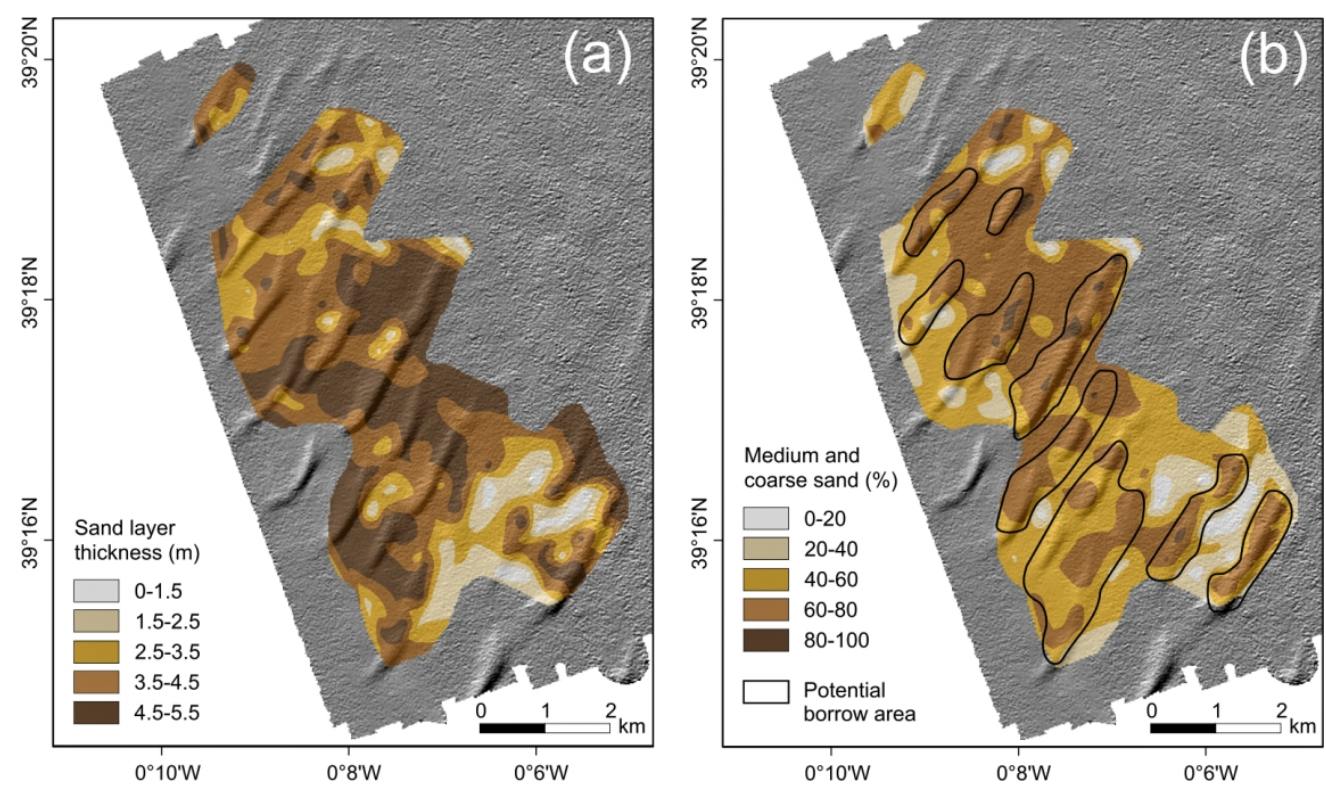

Figure 13. Thickness of sediment layers: (a) sand layer overlying the coarse lag. (b) Spatial distribution of the medium and coarse sand content of the sandy deposits overlying the coarse lag.

$134 \times 78 \mathrm{~mm}(300 \times 300 \mathrm{DPI})$ 